\title{
How Do Interruptions Affect User Contributions on Social Commerce?
}

\begin{abstract}
Social commerce is an extension of e-commerce, in which social media is leveraged to promote user contributions. Our study asks how interruptions in relation to interface design influence two types of user contributions: creating shared content and appreciating others' content. We use two interface designs, pagination and infinite scrolling, to manipulate the extent of interruptions to social commerce users. Based on the capacity theory of attention, we develop five hypotheses. We empirically test our model using a lab experiment and a field study to show that interruptions reduce users' content appreciation but increase their content creation, and that user characteristics moderate these effects. The theoretical and practical contributions of our study are discussed.
\end{abstract}

Keywords: Human-computer interaction, interruption, interface design, pagination, infinite scrolling, user contributions.

\section{Introduction}

Now more than ever, the promise of electronic commerce and online shopping will depend to a great extent upon the interface and how people interact with the computer. (Lohse \& Spiller, 1998, p. 81)

Social commerce is 'a subset of e-commerce that involves using social media to assist in ecommerce transactions and activities' (Liang \& Turban, 2011). Empowered by ubiquitously accessible and scalable social networks, social commerce enables users to seek product information, share and recommend their favourite products, create product collections and interact with other shoppers (Wang \& Zhang, 2012). Stephen and Toubia (2010) remarked that 'social commerce networks between sellers can play an important economic, valuecreating role' (p. 226). This increases the bargaining power for buyers and the profit margin of sales for sellers by lowering the costs of marketing. It has been observed that social

This is the author manuscript accepted for publication and has undergone full peer review but has not been through the copyediting, typesetting, pagination and proofreading process, which may lead to differences between this version and the Version of Record. Please cite this article as doi: 10.1111/isj.12266

This article is protected by copyright. All rights reserved. 
commerce is growing at amazing rates (Olbrich \& Holsing, 2011). There are a few examples of success. Pinterest had attracted 175 million monthly active users as of April 2017, following its launch in 2010 (Turban, Whiteside, King, \& Outland, 2017), making it one of the fastest-growing social commerce sites. The leading social commerce site for female fashion in China, Meilishuo, was founded in November 2009. In 2016, it merged with the second-largest site, Mogujie, to create a combined business worth RMB 3 billion (Wang, 2016). However, most other social commerce sites face intense competition because of a low barrier to entry and thousands of shopping choices (Kassim, Othman, \& Zamzuri, 2016). Thus, their sustainability is uncertain. If users do not contribute product ratings and recommendations to the sites or interact with other shoppers, social commerce is no different from ordinary e-commerce and can easily become obsolete like many other e-commerce sites. The fact that sustainability of social commerce hinges on user contributions motivated us to examine the interface features on social commerce sites that can stimulate user contributions.

We looked at two types of user contributions: (1) creation of shared content; and (2) appreciation of others' content. A closer examination of these types of contributions indicates that the underlying psychological mechanisms for these contributions differ. Creating shared content may relate more to personal identity verification (Ma \& Agarwal, 2007). Appreciating others' content may relate more to reciprocity and social relationship building (Butler, Sproull, Kiesler, \& Kraut, 2002). The two contributions also differ in the amount of cognitive effort required. We argue that creating shared content requires more cognitive effort than using a simple 'Like' click to appreciate others' content.

We are interested in how interruptions affect the two types of user contributions. An interruption is 'a break in task activity, evidenced by observed cessation of a task' (Healey, Sevdalis, \& Vincent, 2006, p. 590). It distracts users from continuing the initial task and may lead to a task switch (Persoon, Broos, Witjes, Hendrikx, \& Scherpbier, 2011). Prior studies on e-commerce show that interruptions often exert a negative effect on user behaviour (McCoy, Everard, \& Loiacono, 2009; Ayyagari, Grover, \& Purvis, 2011). However, their findings may not apply to social commerce, because e-commerce users often have a focused task; in contrast, social commerce users face multiple tasks (such as creating content and 
liking shared content). When interruptions occur, these users may switch from one task to another. Drawing on the capacity theory of attention and the literature of interruption, we argue that interruptions lead to different user contributions. We further examine how user characteristics moderate the effect of interruptions on user contributions. Examining the moderation effects allows us (1) to understand how user characteristics differentiate the effects of interruptive interfaces on user contributions, and (2) to use these user characteristics to form the boundary of the effects of interruptive interfaces (Muller, Judd, \& Yzerbyt, 2005).

In this study, we conducted a lab experiment and a field study to test the effects of interruptions on user contributions. Unlike previous studies, which manipulate the occurrence of interruption with online prompts (such as McCoy et al., 2009 and Chan, Jiang, \& Tan, 2010), we manipulate this variable with a more natural approach. To elaborate, in social commerce, there are two major interface designs: pagination and infinite scrolling. Pagination pauses users at the end of each 'page', which interrupts their tasks at hand. Conversely, infinite scrolling automatically amends content as users approach the bottom of the page, which minimises interruptions. Therefore, pagination results in more interruptions than infinite scrolling. Using this manipulation in an experiment is not only less artificial, but also aligns with Meilishuo's change in interface from pagination to infinite scrolling in 2012. This enables us to use behavioural data from Meilishuo to construct a panel dataset for testing our hypotheses in relation to interruptions.

\section{Background and Literature Review}

\subsection{Social Commerce}

Social commerce comprises elements that promote social interaction as its core functionality. Examples of social elements include customer ratings and reviews, user recommendations and referrals and discussion forums to share shopping experience (Olbrich \& Holsing, 2011). These elements enable users to interact and create content (such as feedback, reviews, ratings and testimonials) for promoting products. Collective intelligence strengthens the traditional 
search and purchase processes to facilitate online shopping (Laudon \& Traver, 2009). The integration of Web 2.0 and social media leads to the functionalities described below.

\subsubsection{Creating: Creating shared content}

This main function involves creating content to share one's favourite products. Users can upload product images or post product links. Users can also attach tags and descriptions to products and organise their favourite products in various collections.

\subsubsection{Liking: Appreciating others' content}

Users can browse products shared by other users and 'like' products that appeal to them. Adding a 'like' shows a reader's preference for the product and appreciation for the original poster. The total number of 'likes' a product receives is always displayed. This serves a social function by offering positive feedback directly to the poster.

\subsubsection{User profile}

Each user can create a personal profile on his or her home page (see Figure 1). On the personal profile, most users use tagging to disclose information, such as product styles they prefer and their hobbies and interests. Some users create personal statements and/or vision statements. Personal statements describe their tastes, personalities, professions and product preferences, and they use tags in their descriptions. Examples of tags include 'good at clothes matching', 'vintage style', 'stylist', 'fashion editor' and 'specialising in shoe design'. In addition to these personal statements, users may provide vision statements that describe their fashion sense or provide their contact information for others to reach them. In Figure 1, the user included her microblog account, through which others might contact her. 


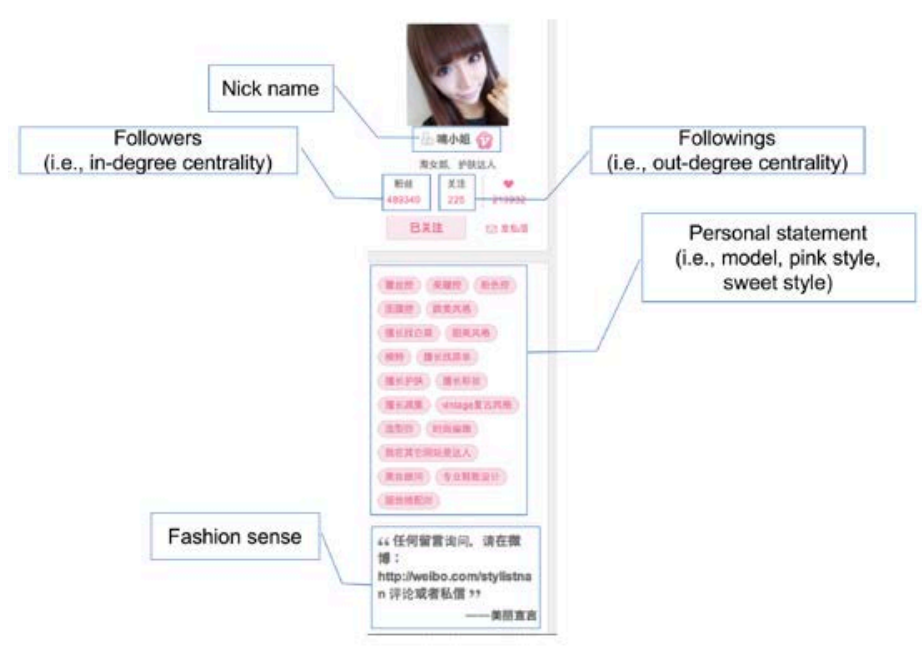

Figure 1: User Profile on Social Commerce Site

\subsubsection{Social networking: Directed social network}

Social commerce has incorporated social networking functions. A user can subscribe to other users' posts by following them. This forms a directed social network. The number of outbound links from a user to others indicates the user's immersion in the community and attention paid to others' content (Stephen \& Toubia, 2010). The number of inbound links from others to the user indicates his or her popularity on the site and the amount of attention others paid to his or her posts (Stephen \& Toubia, 2010). Unlike social media, the 'following' relationship does not require mutual consent or reciprocation on social commerce sites.

\subsection{User Contributions in General Online Communities and Consumer Communities}

So far, scant research has examined user behaviour with regard to social commerce. The literature focuses on online communities, in which users share ideas but cannot transact with one another (Cheema \& Kaikati, 2010; Cheung \& Lee, 2012; Faraj, Kudaravalli, \& Wasko, 2015). Many studies take a motivational perspective with an emphasis on perceived benefits and perceived costs to discuss user contributions to online communities. Xia, Huang, Duan, and Whinston (2012) investigated users' continued sharing behaviour as a private contribution to the public good. They used a dataset from a music-sharing network to test

This article is protected by copyright. All rights reserved. 
whether reciprocity drives users to continue sharing music. They found that the more benefit users 'get' from the network, the more likely they are to continue sharing.

Regarding information sharing, Hennig-Thurau, Gwinner, Walsh, and Gremler (2004) identified five motivators: focused-related utility, consumption utility, approval utility, moderator-related utility and homeostasis utility. Berger and Schwartz (2011) investigated user contributions to online reviews. They used the opportunity of a marketing campaign for a restaurant chain to conduct a field experiment that involved disseminating product information to 1,500 subjects and examining whether these subjects distributed online reviews about the restaurant. The authors also conducted a controlled experiment to complement the field experiment. They found that salient posts attract reviews soon after the posts were uploaded, but after a while, there were no more follow-up reviews because people switched to newer posts.

O'Reilly and Marx (2011) identified three types of motivation (self-worth, risk avoidance and negative bias enactment) that drive user contributions to online reviews. They conducted a qualitative study with nine subjects using purposeful sampling and empirically demonstrated that review credibility is based on the polarity and quantity of posts, the logic and articulation of posts, the ability to find corroborating sources and subjects' previous experience with some sellers. Appendix 1 summarises related studies in the leading information systems (IS) and marketing journals. We do not aim to provide an exhaustive list of publications on the related topics.

Prior studies have some common features. First, they have often used a motivational perspective (such as examining benefits and costs) to explain user contributions (Cheema \& Kaikati, 2010; Cheung \& Lee, 2012). Such motivational factors are intrinsic and beyond the control of site owners. In contrast, we examined the effect of interruptions in relation to layout design (which can be controlled by site owners) on user contributions from the perspective of attention allocation. Appendix 2 summarises interface design related studies in the leading IS journals. Second, most research has considered knowledge sharing in general. Only a few studies have investigated social relational contribution activities, although some have indicated that social relational activities influence knowledge sharing (Liang \& Turban, 2011; Kane, Alavi, Labianca, \& Borgatti, 2014; Faraj, Jarvenpaa, \& Majchrzak, 2011). 
Adding to prior studies, our study distinguished between creating shared content and appreciating others' content. We also considered users' social characteristics and examined their effect on the relationship between interruptions and user contributions. Third, most studies have relied on perceptual data to examine user participation in online communities. Straub, Limayem, and Karahanna-Evaristo (1995) argued that actual and perceived usage are not always congruent. Instead of using self-reported contributions, we captured users' behaviour in a lab experiment and a field study to operationalise user contributions.

\section{Theoretical Background}

\subsection{Capacity Theory of Attention}

Psychologists have long recognised that attention is a limited resource (Kahneman, 1973; Chajut \& Algom, 2003). Attention is a concept that involves selective resource allocation for tasks. Kahneman (1973) noted that 'completion of a mental activity requires two types of input to the corresponding structure: an information input specific to that structure, and a nonspecific input, which may be variously labelled "effort", "capacity", or "attention"” (p. 9). A remark by Eriksen and James (1986) that '[a]ttention can be conceived of as a limited supply of processing capacity, or resources, that can be allocated in varying amounts to different tasks' (p. 225) highlights scarcity of attention. In contemporary society, which is even more complex and filled with information, attention is an even scarcer resource (Davenport \& Beck, 2001).

Kahneman's (1973) capacity theory of attention proposes a model of attention. It posits that attention is limited in overall capacity; that an individual's ability to perform simultaneous tasks depends on how much 'capacity' these tasks require. When the demand for attention exceeds the availability of attention, the individual's ability to perform these tasks is inadequate (Norman \& Bobrow, 1975). In addition, research on cognitive psychology suggests that people have limited working memory to process incoming information (Baddeley, 1992). When there is too much incoming information, at least one activity may be neglected. However, the allocation of attention is not an all-or-none arrangement. The theory further considers a possible split-attention effect (Tarmizi \& Sweller, 1988). 
One interesting example of the split-attention effect is the work of Mayer and Moreno (2002). They examined this effect in the context of learning. When students viewed an animation and read text on screen at the same time, their recall performance was worse than for those who viewed the animation and listened to the narration. These authors argued that visual working memory was scarce but could be divided between tasks. Since processing text on a screen required visual working memory that was also needed for processing the animation, visual working memory was divided between the two tasks; accordingly, their recall performance was reduced. ${ }^{1}$ That said, performing several tasks simultaneously is possible when attention capacity is divided among the activities.

The scarce attention resource is always a problem in e-commerce. The visual channel is associated with a heavy cognitive load because of on-screen text and pictorial information. As of April 2018, the world boasted more than 1.8 billion websites according to Internet Live Stats; this indicates scarcity of attention is now an even bigger issue in e-commerce. This motivates IS researchers to examine website design to retain users' attention (Hsieh \& Chen, 2011; Jiang \& Benbasat, 2007; Kuisma, Simola, Uusitalo, \& Öörni, 2010; Lee \& Benbasat, 2003; Nah, Eschenbrenner, \& DeWester, 2011). Attention allocation is affected by design features, such as web animations in a search task (Zhang, 2000), web flashes (Hong, Thong, \& Tam, 2004a), and pictures and videos in Internet advertising (Hsieh \& Chen, 2011).

\subsection{Influence of Interruptions}

An interruption impedes an individual's attention on a primary task and prompts the individual to attend to the interruption. This causes discontinuity in task (Brixey et al., 2007). Interruptions can lead to both positive and negative outcomes in the workplace (Murata, 1994; Speier, Vessey, \& Valacich, 2003; Ren, Kiesler, \& Fussell, 2008). On the positive side, interruptions divert individuals' attention to important events; this makes it easier to allocate cognitive resources to events that lead to valuable output. On the negative side, interruptions cause distraction and reduce work performance.

\footnotetext{
${ }^{1}$ Mayer and Moreno (2002) also discussed dual processing; that is, processing through both visual and auditory channels. As it is not relevant to the current study (because all information is presented through the social commerce page visually in our setup), we do not elaborate on it.
} 
Whether positive or negative outcomes are achieved is relevant to interruption type (Murata, 1994; Parnin \& Rugaber, 2011). Interruptions are generally classified into two main types. Unexpected interruptions that alter the flow and continuity of a person's work and bring that work to a temporary halt are called intrusions, whilst planned or spontaneous recesses from work on a task that interrupt the task's flow and continuity are called breaks (Jett \& George, 2003). In our study, interruptions brought by pagination are anticipated, so they are breaks. Although breaks bring delays to a task, they alleviate fatigue and restore attentional resources (Coker, 2011). Breaks also provide an opportunity for the incubation of ideas (Elsbach, 2001; Jett \& George, 2003), in which individuals cease to focus on the original task and their subconscious 'continues to operate and make connections between seemingly disparate streams or thought' (Jett \& George, 2003, p. 499) and thus contributes to the initiation of creative ideas (Baird, Smallwood, Mrazek, Kam, Franklin, \& Schooler, 2012; Csikszentmihalyi \& Sawyer, 1995; Ritter \& Dijksterhuis, 2014). In addition to the opportunity for the incubation of ideas, breaks also create natural occasions of task switching (Persoon et al. 2011).

\subsection{Layout Design: Pagination vs. Infinite Scrolling}

Pagination divides web content into discrete pages and explicitly asks users to click 'next page' to continue. In contrast, infinite scrolling skips clicking by using two functions: endless scrolling and dynamic grids. Endless scrolling is a technique in which additional content for a web page is added dynamically to the bottom of the page as the user approaches the end (Loranger, 2014). This convenience increases the average time a user spends on a website as well as scrolling efficiency (Buchanan, Paine, Joinson, \& Reips, 2007). In addition, infinite scrolling provides grids. The width and height of a grid is dynamically generated to match the adjacent cells so as to fill up all surrounding blank space. Dynamic grids cram as much content as possible onto a single page; presumably, the more a social commerce site shows users, the more likely users are to find something they like.

Figures $2 \mathrm{a}$ and $2 \mathrm{~b}$ illustrate pagination and infinite scrolling, respectively. There are two differences. First, at the bottom of Figure 2a, there is a list of page numbers. After a user clicks a number, a new page of products is loaded. Figure $2 b$ does not contain such a list 
because more products are automatically loaded whenever a user reaches the 'bottom' of the page. Second, Figure 2a contains a rectangular grid whereby one product falls into each cell of the grid, regardless of image size or description length. In contrast, Figure $2 b$ uses a dynamic grid layout in which items of a similar size are aligned and placed near each other.

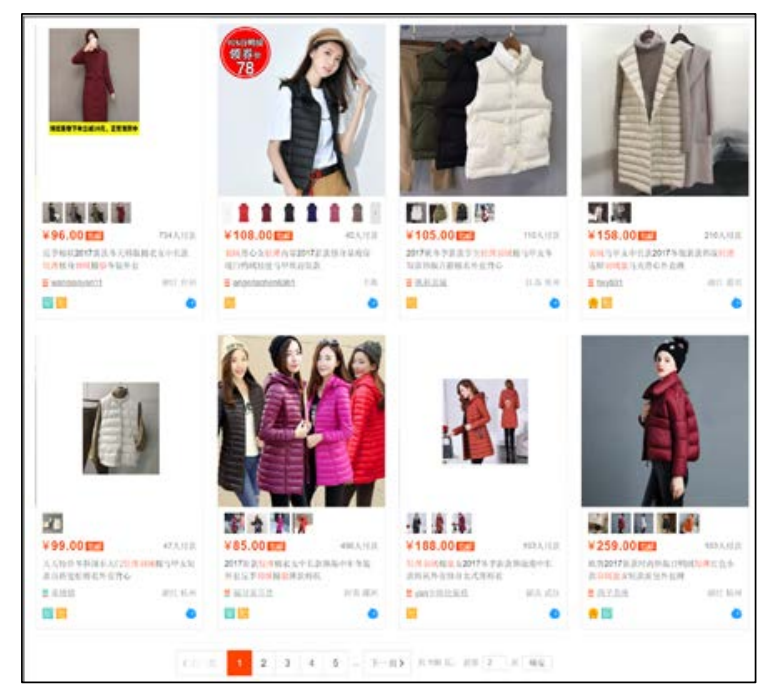

Figure 2a: Pagination
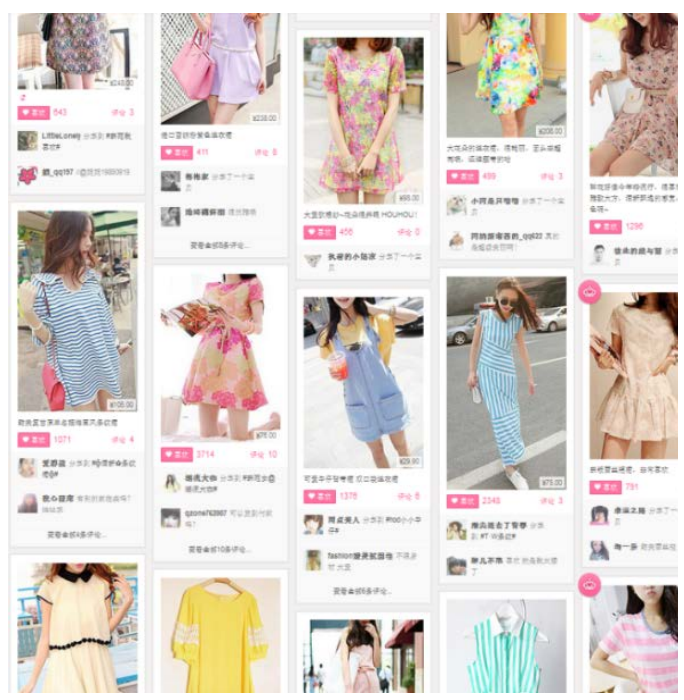

Figure 2b: Infinite Scrolling

Figure 2. Two Types of Social Commerce Interface

The two layouts affect attention allocation in three ways. First, compared with pagination, infinite scrolling removes interruptions to browsing, making content loading more efficient than with pagination. This makes users more engaged in reading others' content and experience flow-a state of complete immersion in an activity (Csikszentmihalyi, 1975). However, this immersed browsing may drain attentional resources and lead to fatigue. Second, infinite scrolling enables users to easily view hundreds of shared items through just a few scrolls downward. It increases the total attention users pay to others' posts; however, each post receives less attention on average. Third, based on Section 3.2, pagination imposes more interruptions on users than infinite scrolling does. These interruptions are 'breaks', which alter user contribution behaviour. This concept is discussed further in Section 4.

\section{Hypothesis Development}

Figure 3 depicts the research model. We developed five hypotheses. The first two hypotheses examined the direct effect of interruption on the two types of user contributions. The next 
three hypotheses examined how user characteristics (i.e., self-disclosure, out-degree centrality and in-degree centrality) moderate the main relationships between interruptions and the two types of user contributions.

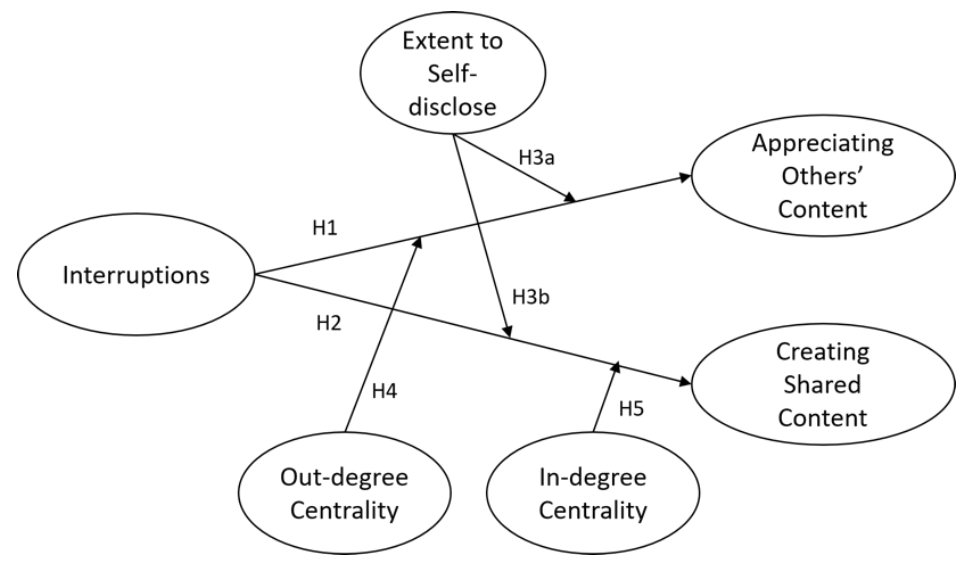

Figure 3: Research Model

\subsection{Effects of Interruption on the Two Types of User Contribution}

Interruptions exist on social commerce sites in various forms. They can be pop-up advertisements (intrusions), unaligned grid displays (intrusions) or a required click of the 'next page' button in pagination (a break). They may distract users from the current task (Guo \& Poole, 2009), impair task processing, reduce task accuracy (Cellier \& Eyrolle, 1992; Iqbal \& Bailey, 2010) and increase the time required for task completion (Jenkins, Anderson, Vance, Kirwan, \& Eargle, 2016; Schiffman \& Griest-Bousquet, 1992).

In $\mathrm{H} 1$, we argued that, compared with infinite scrolling, pagination produces more interruptions for browsing, which reduces appreciation of others' content. This is because, when reaching the end of the page, pagination prompts users to 'stop' and 'resume' and explicitly urges users to click the 'next' button to continue. The interruptions on pagination reduce users' ability to sustain mental attention (Jett \& George, 2003). In contrast, infinite scrolling makes page switching transparent. It causes fewer interruptions to user attention. Since users do not realise the 'end' of the page, their reading experience is more engaging. As a result, infinite scrolling enables users to read more; since users are more likely to encounter content they like, the number of likes they give to others' posts may increase. 
H1: A less interruptive interface leads to more user appreciation of others' content than a more interruptive interface.

Next, we discuss the effect of interruptions on creating shared content. The two activities, appreciating others' content (as discussed in H1) and creating shared content (to be discussed in H2), have subtle differences. To appreciate others' content, a user simply clicks a 'like' button. Clicking a button is a unified act that consumes minimal cognitive resources. In contrast, when a user creates content, the user must think about what to put in the shared content. Of the two activities, appreciating others' content occurs at a lower operating level. Therefore, when browsing social commerce sites, it is easier for users to stop browsing and click a 'like' button than to create shared content.

Pagination requires users to click the 'next page' button before proceeding to a new page. This click request is an interruption, specifically a break, to users. Breaks reduce fatigue and restore attentional resources (Coker, 2011). In other words, when users switch their attention from glancing through the product list to clicking the 'next page' button, their attentional resources are restored. In addition, after this click, users pause. The pause creates a natural occasion for a task switch (Jin \& Dabbish, 2009; Persoon et al. 2011). Users may not immediately start glancing through the product list on the new page. This reduces the chance of users continually engaging in primitive tasks, i.e., appreciation of others' content, in our research setup.

Furthermore, the restoration of resources enabled by the break also provides a chance for the incubation of ideas (Elsbach, 2001; Jett \& George, 2003). Users can connect to seemingly disparate thoughts and shift to related tasks (Jett \& George, 2003). Since their attentional resources are restored after the break, they can engage in tasks that require more cognitive resources (Baird et al., 2012; Csikszentmihalyi \& Sawyer, 1995; Ritter \& Dijksterhuis, 2014) and create new posts. Overall, interruptions resulting from pagination stimulate users to pause glancing, restore attentional resources and initiate creative ideas. Therefore, we hypothesised that interruptions brought by pagination lead to more creation of shared content. 
H2: A more interruptive interface leads to more creation of shared content than a less interruptive interface.

\subsection{Interaction Effect of Extent to Self-disclose with Interruptions}

$\mathrm{H} 3 \mathrm{a}$ and $\mathrm{H} 3 \mathrm{~b}$ investigated the interaction between interruptions and users' extent to selfdisclose. In practice, some users disclose more information about their identity or tastes. They express their opinions about others' posts. When they read posts that match their preferences, they give out 'likes'. In contrast, some users are reluctant to share their identity or tastes (Lee, Im, \& Taylor, 2008). These users are more reserved and more cautious when appreciating others' content.

According to $\mathrm{H} 1$, a social commerce interface with fewer interruptions leads to greater appreciation of shared content. We argued that this effect is stronger for users with a high extent of self-disclosure than those with a low extent of self-disclosure because users with a high extent of self-disclosure are eager to express their opinions. They have a strong tendency to click the 'like' button to express their support for favourable posts. Combined with efficient browsing supported by an interface with fewer interruptions, we anticipated that the increase in the number of 'likes' resulting from a less interruptive interface would be more salient for users with a high extent of self-disclosure than for those with a low extent of selfdisclosure.

H3a: The positive effect of a less interruptive interface on content appreciation (as specified in H1) is stronger for users with a high extent of self-disclose than for those with a low extent of self-disclosure.

Users with a low extent of self-disclosure are more cautious when creating shared content because they are hesitant to share their views. According to $\mathrm{H} 2$, a social commerce interface with more interruptions prompts users to pause, which provides them with a chance to engage in complex tasks and generate new ideas (Jett \& George, 2003). Users with a high extent of self-disclosure shares their ideas with others, and as a result, the amount of content they create increases. In contrast, users with a low extent of self-disclosure have a weak tendency to share their ideas with others. Overall, the positive effect brought by a more 
interruptive interface on content creation is more salient for users with a high extent of selfdisclosure.

H3b: The positive effect of a more interruptive interface on content creation (as specified in H2) is stronger for users with a high extent of self-disclose than for those with a low extent of self-disclosure.

\subsection{Social Network Degree Centrality}

In social commerce, users have social ties, i.e., they follow other users and are followed by others. Because social ties have directions, this forms a directed network structure in which each user is a 'node'. Degree is a simple centrality measure that counts how many neighbours a node has. There are two measures of degree centrality. In-degree centrality is the number of incoming links, or the number of followers a user has. Out-degree centrality is the number of outgoing links, or the number of others a user follows (Scott, 2000).

$$
\text { InDegreeCentrality }_{i}=\sum \text { Follower }_{i} \text { OutDegreeCentrality }_{i}=\sum \text { Followings }_{i}
$$

Previous research has examined how in-degree and out-degree centrality influence user behaviour. Huang, Chen, Ou, Davison, and Hua (2017) found that social interaction ties are crucial for enhancing information exchange because a network with more ties provides a cost-effective way for users to obtain the required information and avoid unrealistic expectations in transactions. Peng and Dey (2013) indicated that the structure of a network determines information and knowledge flow. Wu (2013) found that information-rich social networks are enabled by the Internet and the extent of information richness of such networks is associated with user contributions. In the following sections, we examine how network degree centralities interact with interruptions to influence user contributions.

\subsubsection{Interaction Effect of Out-degree Centrality and Interface Type}

First, we focused on out-degree centrality. Mossholder, Settoon, and Henagan (2005) suggest that a user with high out-degree centrality follows many other users because he or she likes reading others' posts. Also, high out-degree centrality implies that it is easy for the user to access others' posts. In H4, we compared the behaviour of appreciating others' content by users with high versus low out-degree centrality. According to H1, a less interruptive 
interface leads to more content appreciation. We argued that this increase is amplified for users with high out-degree centrality, for two reasons. First, a less interruptive interface enables users to continue engaging in a 'flow' state. Because users with high out-degree centrality enjoy reading others' posts more than those with low out-degree centrality, the engagement in flow is amplified for the former more than for the latter. Second, users with high out-degree centrality have more ties and thus can easily find relevant posts through connected people in whom they are interested. The combined effect of the ease of accessing interesting posts and the ease of browsing relevant posts enabled by a less interruptive interface stimulates users with high out-degree centrality to continue browsing and appreciate more posts. Hence, we hypothesised:

H4: The positive effect of a less interruptive interface on content appreciation (as specified in H1) is stronger for users with high out-degree centrality than for those with low out-degree centrality.

\subsubsection{Interaction Effect of In-degree Centrality with Interface Type}

Next, we focused on in-degree centrality. Users with high in-degree centrality are followed by many other people. These users receive a lot of attention from other users and perceive themselves to be 'popular' in a social network (Scott, 2000). These users have a desire to maintain their 'popularity' and like to compete for attention (Hansen \& Haas, 2001; Shen, $\mathrm{Hu}, \&$ Rees, 2015).

The direction of the effect of interruption on created content was anticipated to be the opposite for users with high versus low in-degree centrality. Based on $\mathrm{H} 2$, an interface with fewer interruptions does not give users a chance for incubation, which results in less created content. This decrease was anticipated to be less salient for users with high in-degree centrality. A less interruptive interface enables fast scrolling, such that it is hard for a single post to stand out. Given that users with high in-degree centrality desire to draw others' attention, they are likely to create more shared content to compensate for the possible loss of others' attention caused by fast scrolling. Conversely, because users with low in-degree centrality have less of a need to be popular, they behave naturally given a less interruptive interface. That is, based on $\mathrm{H} 2$, they create less shared content. Overall, we hypothesised: 
H5: The negative effect of a less interruptive interface on content creation (as specified in H2) is weaker for users with high in-degree centrality than for those with low in-degree centrality.

\section{Research Method and Setting}

We conducted two studies to test the above hypotheses. A lab experiment was used to test the main effects of interruptions ( $\mathrm{H} 1$ and $\mathrm{H} 2$ ) on user contributions. The second study was a field study. We leveraged the opportunity provided by an interface change from pagination to infinite scrolling by Meilishuo. Behavioural data from more than 1,000 users before and after the interface change were collected. We constructed a panel dataset and ran negative binomial regression analyses to test the full research model.

\subsection{Study 1: A Lab Experiment}

\subsubsection{Subjects and experimental setup}

We conducted a lab experiment to test $\mathrm{H} 1$ and H2. These two hypotheses were grounded in the theories of cognitive psychology and the control environment of the lab experiment enabled us to precisely test the effect of interruptions on user contributions. Subjects were asked to use a social commerce site for books; they could browse books, choose to like book items, create shared items and add books to shopping baskets. There were two groups: one group used a site with a more interruptive interface (pagination); the other used a site with a less interruptive interface (infinite scrolling). Subjects were randomly assigned to one of the two groups.

With student subjects, we used books as the context since books were relevant to their studies and lives. To make the content of the experimental website realistic, we used Amazon application programming interfaces to download information on books in the business category. In addition, we downloaded related book reviews written by real users on Amazon. On the experimental site, we categorised these books into six topics (accounting, economics, finance, IS, marketing and management) and let subjects choose the topic they planned to browse. This further increased their involvement in our experiment. 
In the experiment, subjects first completed a short questionnaire designed to collect demographic information. Subsequently, they were tasked to select a book on the site. Figure 4 presents screen captures of the website interfaces. The home page listed the six topics. ${ }^{2}$ After subjects clicked a topic, they would see a list of book items. Each screen page displayed eight book items. We randomly generated the number of 'likes' a book item had received, and the book reviews were real reviews from Amazon. In the experiment, it was voluntary for subjects to 'like' a book item and/or create a shared book item.

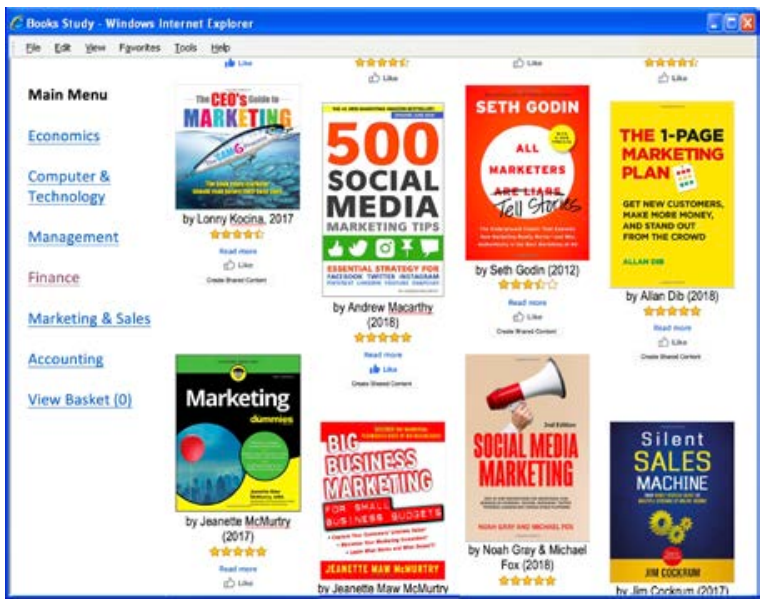

Figure 4a. Level 0 Main Page with Infinite Scrolling

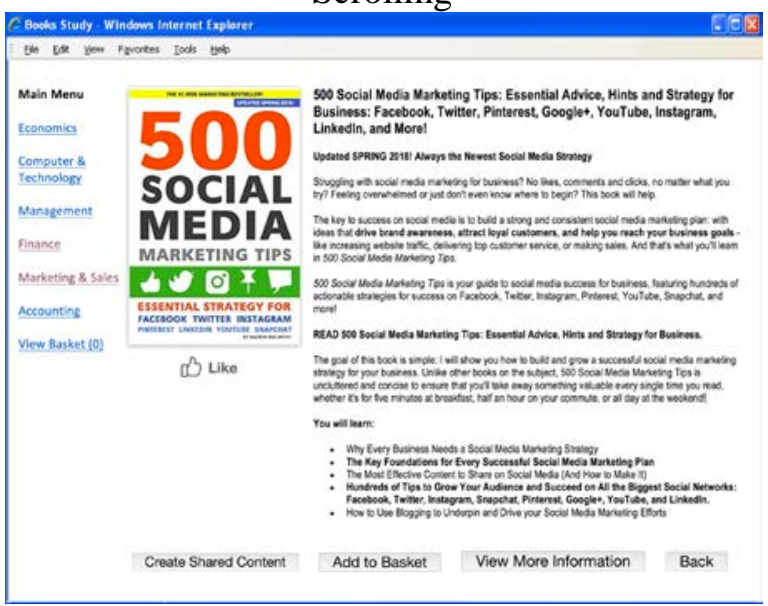

Figure 4c. Book Details (Level 1)

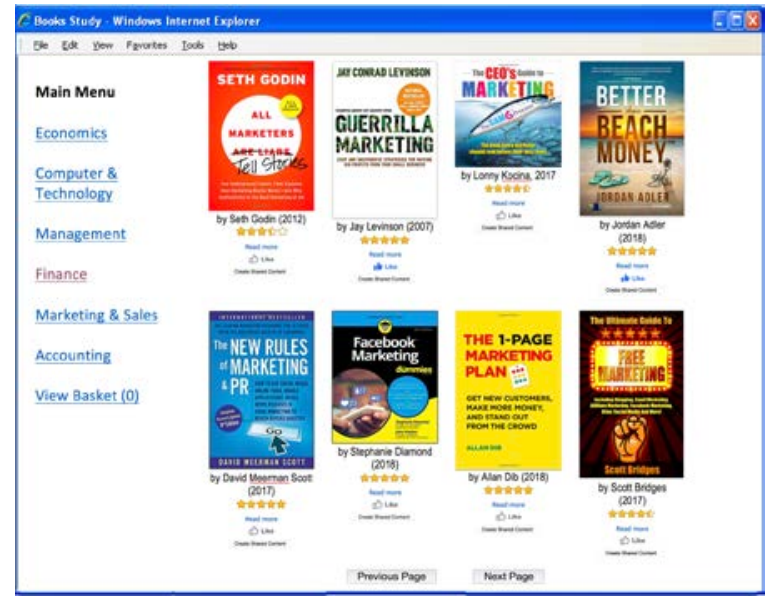

Figure 4b. Level 0 Main Page with Pagination

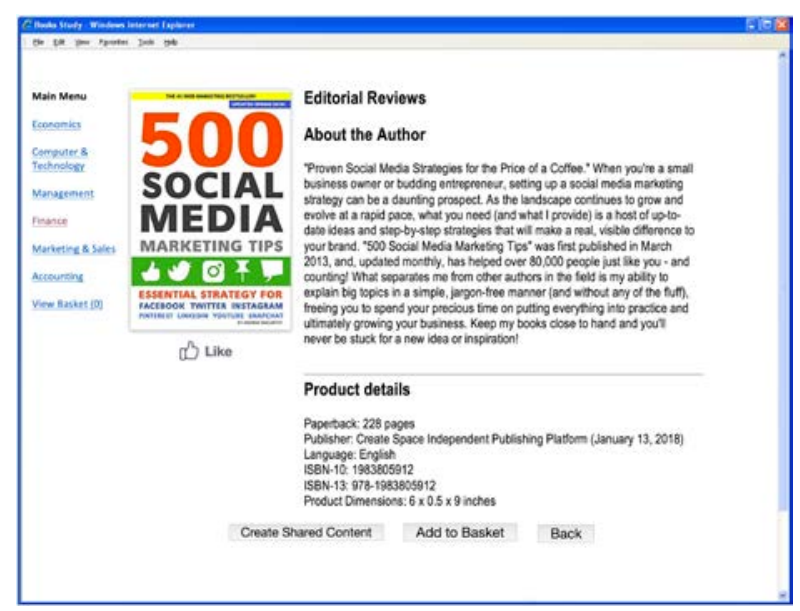

Figure 4d. Book Details (Level 2)

\footnotetext{
${ }^{2}$ When subjects started the experiments, they entered the home page (level 0) of the site. After they clicked on a book item, they were forwarded to the book's profile page (level 1). Subjects could browse further information (level 2) about the book item by clicking on the "View More Information" button.
} 
Figure 4. Screen Capture of the Lab Experiment Social Commerce Site

During the book selection process, subjects could browse the books and click an item to view information about the author and a description of the book. They could also choose to 'like' a book. They could share new book items by uploading book titles and a 100-word description. Throughout the process, the subjects could add any number of books to their shopping basket and then select one to be their final choice.

\subsubsection{Subjects and the pilot test}

Prior to the main experiment, we conducted a pilot test with six subjects to check the performance of the download system. All subjects could complete the entire experiment within 30 minutes and they confirmed that the process was smooth.

We recruited 70 students to participate in the main experiment: 32 males and 38 females. Their average age was 20 , with a range of $17-25$. The 70 subjects were randomly assigned to one of the two groups. There were 36 subjects in the more interruptive interface group and 34 in the less interruptive interface group.

\subsubsection{Hypothesis testing}

Table 1 presents descriptive statistics for the lab experiment. The two user behaviours of interest were liking (Like) and creating shared content (Create). In addition to these two user behaviours, we kept track of the number of book items that a user browsed (Browse at level 0 ) and clicked to view book details (Browse at levels 1 and 2) and the number of book items added to the basket (Basket).

Table 1. Descriptive Statistics of the Lab Experiment

\begin{tabular}{lrrrrrrrr}
\hline & \multicolumn{3}{c}{$\begin{array}{c}\text { Interfaces with More Interruptions } \\
\text { (Pagination) }(\mathrm{N}=36)\end{array}$} & \multicolumn{4}{c}{$\begin{array}{c}\text { Interfaces with Fewer Interruptions } \\
\text { (Infinite Scrolling) (N=34) }\end{array}$} \\
\hline & Mean & \multicolumn{1}{c}{ S.D. } & Min & Max & Mean & S.D. & Min & Max \\
\hline Number of 'likes' & 2.89 & 1.21 & 1 & 5 & 11.06 & 3.72 & 5 & 18 \\
\hline Number of creations & 5.00 & 2.59 & 2 & 13 & 3.79 & 1.34 & 1 & 6 \\
\hline Level 0 browsing & 50 & 27.14 & 24 & 120 & 155.82 & 79.18 & 56 & 344 \\
\hline Level 1 browsing & 12.42 & 3.49 & 7 & 19 & 20.18 & 5.66 & 10 & 33 \\
\hline Level 2 browsing & 6.94 & 2.72 & 3 & 16 & 14.53 & 4.91 & 6 & 24 \\
\hline
\end{tabular}


Items added to basket

6.03

1.21

6.65

1.98

$3 \quad 10$

Note: Level 0 is the book items browsed at level 0; each screen contains eight book items. Level 1 is the book profile page of a specific book item and level 2 is the detailed information of a specific book item. When browsing the list of book items at level 0 , users can click a book and get to the information page of that specific book, i.e., level 1. To reach level 2, users must first reach level 1, then click the 'view more information' button.

To test H1, we examined the differences in the Like number for the two groups. The mean of book items liked was 2.89 (11.06) for the more (less) interruptive interface group $\left[F(1,68)=155.79, p=0.000\right.$, effect size $\left.\eta^{2}=0.6961\right]$. Thus, $\mathrm{H} 1$ was supported. To test $\mathrm{H} 2$, we examined the differences in the number of created items of the two groups. The mean of created items was 5.00 (3.79) for the more (less) interruptive interface group $[F(1,68)=5.89$, $p=0.0179$, effect size $\left.\eta^{2}=0.0797\right]$. Thus, H2 was supported. Figure 5 illustrates the mean values for the two dependent variables for the two groups, with confidence intervals on the bar graphs.

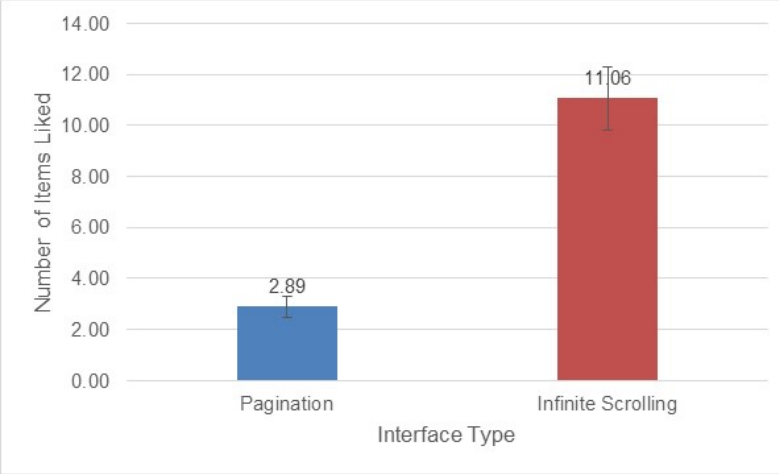

Figure 5a: Number of items liked

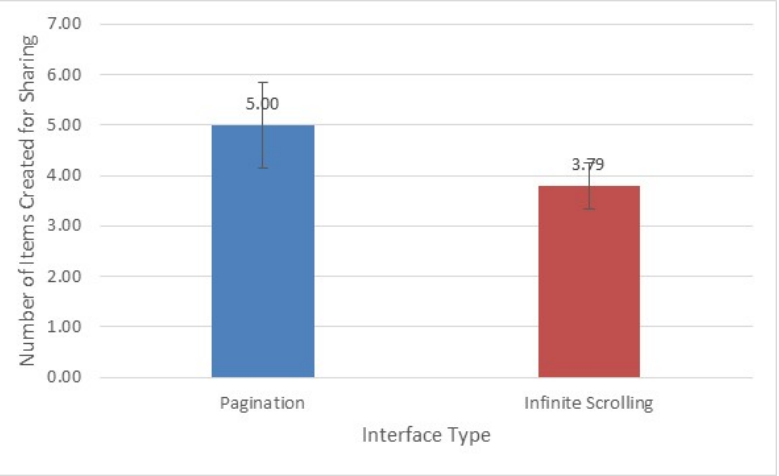

Figure 5b: Number of items created for sharing

Figure 5. Effects of Interruption on User Contributions

We did not hypothesise the effect of interruptions on the amount of browsing or the number of items added to the shopping basket. Thus, we briefly discuss these behavioural measures. The lab experiment allowed us to capture the items browsed at levels 0,1 and 2 . There was a significant difference between interfaces in the mean of items browsed at level 0 , specifically, 50.00 for pagination and 155.82 for infinite scrolling $[F(1,68)=57.23, p=$ 0.000 , effect size $\left.\eta^{2}=0.4570\right]$. The mean of item details browsed at level 1 was 12.42 with pagination and 20.18 with infinite scrolling $\left[F(1,68)=48.26, p=0.000\right.$, effect size $\eta^{2}=$ 
0.4151]. The means of item details browsed at level 2 were, respectively, 6.94 and 14.53 $\left[F(1,68)=64.88, p=0.0000\right.$, effect size $\left.\eta^{2}=0.4883\right]$. This implies that subjects browsed more book items with a less interruptive interface. Regarding the number of books added to the basket, the mean was 6.03 for pagination and 6.65 for infinite scrolling, which did not represent a significant difference $[F(1,68)=2.52, p=0.1168]$.

In addition, we found that interruptions resulting from the 'next page' button on a pagination layout stimulated subjects to actively browse web pages at levels 1 and 2. To elaborate, infinite scrolling with fewer interruptions stimulated subjects to browse more pages (level 0: 155.82; level 1: 20.18; level 2: 14.53) and pagination with more interruptions influenced subjects to browser fewer pages (level 0: 50; level 1: 12.42; level 2: 6.94). However, user immersion was not sustained with an infinite scrolling interface. When we compared the relative decline of the browsed pages from level 0 to level 1 , the decline was larger for the former group (from 155.82 to 20.18 , i.e., a decline of $87.05 \%$ ) than for the latter group (from 50 to 12.42 , i.e., a decline of $75.16 \%$ ). Similarly, at level 2 , the decline was larger for the former group (from 155.82 to 14.53 , i.e., a decline of $90.68 \%$ ) than for the latter (from 50 to 6.94, i.e., a decline of $86.12 \%$ ). This implies that although infinite scrolling stimulates users to browse a lot of product items on the home page, it cannot effectively retain user interest to explore more product items.

\subsection{Study 2: A Field Study with Meilishuo}

Beginning in the week of 24 March 2012, Meilishuo switched from a more interruptive interface (pagination) to a less interruptive interface (infinite scrolling). This interface change enabled us to examine the effects of interruptions on the two types of user contributions: the creation of shared content (Create) and the appreciation of others' content (Like).

On Meilishuo, users can share their favourite products and interact with others. The shared content focuses on fashion and lifestyle products. Based on an Alexa.com report, Meilishuo had a traffic rank of 995 globally and 144 in China as of April 2013. Meilishuo provides direct sharing features, in which users can post their favourite products by providing pictures or links as well as product descriptions. Users can also include product details, such as product price, tags and information about the online shops that sell the related product. 
Purchases can be made through links to other online stores. Social sharing features are integrated into Meilishuo. Users can like others' shared items, and the products they like will appear on their 'my likes' page. There are social networking features as well. They can 'follow' other users so that they can easily read relevant shared items. In addition, users have their own profiles; they can disclose personal information, upload profile photos and add selfdisclosure tags. Figure 6 depicts a post on Meilishuo.

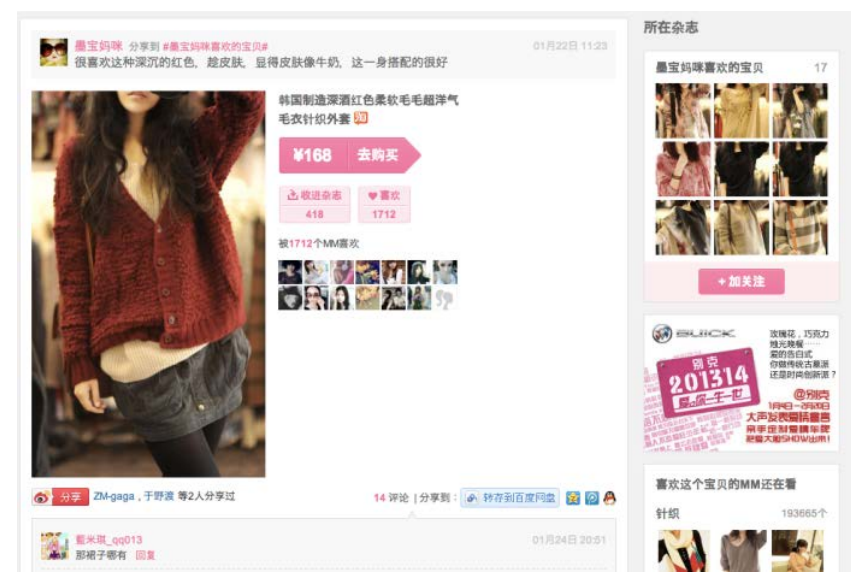

Figure 6. A Screenshot of a Product Post on Meilishuo

\subsubsection{Data}

To determine the length of the examination time frame in our study, we balanced two factors. The time frame could not be too short, or it would not truly reflect user behaviour changes; however, it could not be too long, or it would accumulate too many unrelated activities. Therefore, we chose the period of 3 March-20 April 2012, not including the week of 24-30 March, during which the interface update happened. The resulting period included three weeks before the change (3-23 March, inclusive) and three weeks after the change (31 March-April 20, inclusive).

We randomly sampled 14,000 real users from Meilishuo. For each user in the sample, we recorded the number of times they created shared content and the number of times they appreciated others' content during the study time frame. We also collected users' profile information on 30 April 2012. To ensure the sample included only active users, we focused on users who had posted before 3 March 2012 and who had at least one share or 'like' during 
the first half of 2012. Including inactive users would artificially inflate the significance of the results, so we dropped them from the sample. The resulting sample comprised 1,243 users.

\subsubsection{Operationalisation of constructs}

The constructs in the research model were operationalised as follows. For interface types, we used 0 to represent a more interruptive layout (pagination) and 1 to represent a less interruptive layout (infinite scrolling). In-degree centrality was operationalised as the total number of followers. Out-degree centrality was operationalised as the total number of followings. The extent of self-disclosure was operationalised as the total number of selfdescription tags a user provided on the site. Users could choose to upload personal statements to describe their tastes, personalities, professions and product preferences. They could choose from tags provided by the site or create their own tags. Creating shared content was operationalised as the total number of posts that users uploaded to the site in a week. Appreciating others' content was operationalised as the total number of 'likes' a user provided to others' posts on the site in a week. Table 2 presents the descriptive statistics and correlations of the variables.

Table 2: Descriptive Statistics and Correlations

\begin{tabular}{lccccccc}
\hline Variables & Mean & S.D. & 1 & 2 & 3 & 4 & 5 \\
\hline 1. Weekly number of likes & 6.94 & 20.78 & 1 & & & & \\
\hline 2. Weekly number of creates & 4.34 & 19.24 & 0.098 & 1 & & & \\
\hline 3. No. of self-description tags & 1.90 & 2.59 & -0.005 & 0.026 & 1 & & \\
\hline 4. Out-degree centrality & 69.74 & 588.45 & 0.092 & 0.033 & 0.023 & 1 & \\
\hline 5. In-degree centrality & 5688.29 & 191926.40 & -0.009 & 0.068 & -0.009 & 0.116 & 1 \\
\hline $\begin{array}{l}\text { 6. Experience with the site } \\
\text { (in days) }\end{array}$ & 146.84 & 115.10 & -0.022 & -0.044 & 0.113 & 0.162 & 0.072 \\
\hline
\end{tabular}

\subsubsection{Analysis and Results}

As the dependent variables were counts (i.e., the number of shared items in a week, the number of 'likes' in a week) and were repeated measures of individuals (comprising longitudinal panel data) in the field study, we used a generalised estimation equation (GEE) method with negative binomial specification for data analysis. One strength of GEE is that it considers the correlation of responses within measures from the same subjects over time (Liang \& Zeger, 1986; Zeger \& Liang, 1986; Zeger, Liang, \& Albert, 1988), producing 
efficient, unbiased regression estimates for use in analysing longitudinal or repeatedmeasures research designs with non-normal response variables (Harrison \& Hulin, 1989). The GEE method has been widely used in the medical and life sciences and is recommended for analysis of repeated measures in organisational (Ballinger, 2004) and IS research (Gnyawali, Fan, \& Penner, 2010; Morris \& Venkatesh, 2010). Furthermore, the number of shared items in a week and the number of appreciations in a week were accumulated 'events', which makes them count data. Poisson regression and negative binomial regression are often used to analyse count data (Cohen, Cohen, West, \& Aiken, 2003; Rabe-Hesketh \& Skrondal, 2008). A Poisson regression model is a negative binomial regression model with a heterogeneity of 0 . Negative binomial regression models can also take account of overdispersion in count data, which is a characteristic of the current data. Therefore, we used GEE with negative binomial.

To test H1, we examined the effect of interruption on appreciation of others' posts (Like). We first estimated the baseline model with the variable indicating the difference between a more interruptive interface and a less interruptive one. Then, to eliminate the concern that the differences in users' appreciation was due to time, time dummies of the weeks were included in the model. To control for individual heterogeneity, we further included users' number of self-disclosure tags and their prior experience with the site, measured as the number of days from the first post to the corresponding week. We also included in-degree and out-degree centralities; since these were over-dispersed, we performed a log transformation to reduce over-dispersion.

Table 3 presents the results. Given a less interruptive interface, users were found to give more appreciations to others' posts $(\beta=0.110, p=0.000)$. In the negative binomial model, since $\lambda_{i}=\exp \left(X_{i} \beta\right)$, we could calculate $\exp (\beta)$ and the incidence rate ratio (IRR). For $\beta=0.110$, the IRR was 1.1161, which suggests that the number of likes on a less interruptive interface was $11.61 \%$, higher than on a more interruptive interface, holding all other factors constant. Thus, H1 was supported.

To test H2, we examined the effect of interruption on users' creation of shared content. As shown in Table 3, the results suggest that the introduction of a less interruptive 
interface, i.e., infinite scrolling in the field study, had a significant negative effect ( $\beta=$ $-0.457, p=0.000$ ) on the number of shared posts that users created. The IRR was 0.6330, which suggests that after the introduction of infinite scrolling, the 'expected count' of shared posts became 0.6330 times of the count when pagination was used. As hypothesised, more interruptions caused users to pause and revoke cognitive resources to create more content. $\mathrm{H} 2$ was supported.

This article is protected by copyright. All rights reserved. 
Table 3. Analysis Results of the Main Effects

\begin{tabular}{|c|c|c|c|c|c|c|c|c|}
\hline Variables & $\begin{array}{l}\text { (1) } \\
\text { Like }\end{array}$ & $\begin{array}{l}(2) \\
\text { Like }\end{array}$ & $\begin{array}{l}\text { (3) } \\
\text { Like }\end{array}$ & $\begin{array}{l}\text { (4) } \\
\text { Like }\end{array}$ & $\begin{array}{c}(5) \\
\text { Create }\end{array}$ & $\begin{array}{c}(6) \\
\text { Create }\end{array}$ & $\begin{array}{c}(7) \\
\text { Create }\end{array}$ & $\begin{array}{c}(8) \\
\text { Create }\end{array}$ \\
\hline $\begin{array}{l}\text { Interface types } \\
0 \text { for more interruptive } \\
1 \text { for less interruptive }\end{array}$ & $\begin{array}{l}0.109 * * * \\
(0.0149)\end{array}$ & & $\begin{array}{c}0.211 * * * \\
(0.0255)\end{array}$ & $\begin{array}{l}0.110 * * * \\
(0.0286)\end{array}$ & $\begin{array}{c}-0.701 * * * \\
(0.0208)\end{array}$ & & $\begin{array}{c}-0.621 * * * \\
(0.0358)\end{array}$ & $\begin{array}{c}-0.457 * * * \\
(0.0387)\end{array}$ \\
\hline $\begin{array}{l}\text { Week dummy } \\
\left(3^{\text {rd }} \text { March }-9^{\text {th }} \text { March }\right)\end{array}$ & & $\begin{array}{c}-0.255 * * * \\
(0.0255)\end{array}$ & $\begin{array}{l}-0.0442 * \\
(0.0257)\end{array}$ & $\begin{array}{l}-0.0470 \\
(0.0287)\end{array}$ & & $\begin{array}{c}0.705 * * * \\
(0.0357)\end{array}$ & $\begin{array}{c}0.0839 * * \\
(0.0345)\end{array}$ & $\begin{array}{c}0.0290 \\
(0.0374)\end{array}$ \\
\hline $\begin{array}{l}\text { Week dummy } \\
\left(10^{\text {th }} \text { March }-16^{\text {th }}\right. \\
\text { March })\end{array}$ & & $\begin{array}{c}-0.193 * * * \\
(0.0255)\end{array}$ & $\begin{array}{c}0.0172 \\
(0.0256)\end{array}$ & $\begin{array}{l}-0.0188 \\
(0.0285)\end{array}$ & & $\begin{array}{c}0.820 * * * \\
(0.0356)\end{array}$ & $\begin{array}{c}0.199 * * * \\
(0.0344)\end{array}$ & $\begin{array}{l}0.157 * * * \\
(0.0371)\end{array}$ \\
\hline $\begin{array}{l}\text { Week dummy } \\
\left(17^{\text {th }} \text { March }-23^{\text {rd }}\right. \\
\text { March })\end{array}$ & & $\begin{array}{c}-0.211 * * * \\
(0.0255)\end{array}$ & & & & $\begin{array}{c}0.621 * * * \\
(0.0358)\end{array}$ & & \\
\hline $\begin{array}{l}\text { Week dummy } \\
\left(31^{\text {st }} \text { March }-6^{\text {th }} \text { April }\right)\end{array}$ & & $\begin{array}{c}-0.191 * * * \\
(0.0255)\end{array}$ & $\begin{array}{c}-0.191 * * * \\
(0.0255)\end{array}$ & 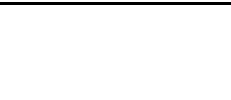 & & $\begin{array}{c}0.167 * * * \\
(0.0365)\end{array}$ & $\begin{array}{c}0.167 * * * \\
(0.0365)\end{array}$ & \\
\hline $\begin{array}{l}\text { Week dummy } \\
\left(7^{\text {th }} \text { April }-13^{\text {th }} \text { April }\right)\end{array}$ & & $\begin{array}{c}-0.150 * * * \\
(0.0254)\end{array}$ & $\begin{array}{c}-0.150 * * * \\
(0.0254)\end{array}$ & $\begin{array}{c}0.0422 \\
(0.0284)\end{array}$ & & $\begin{array}{c}-0.139 * * * \\
(0.0373)\end{array}$ & $\begin{array}{c}-0.139 * * * \\
(0.0373)\end{array}$ & $\begin{array}{c}-0.377 * * * \\
(0.0410)\end{array}$ \\
\hline $\begin{array}{l}\text { Week dummy } \\
\left(14^{\text {th }} \text { April }-20^{\text {th }} \text { April }\right)\end{array}$ & & & & $\begin{array}{l}0.166 * * * \\
(0.0284)\end{array}$ & & & & $\begin{array}{c}-0.213 * * * \\
(0.0406)\end{array}$ \\
\hline Self-disclosure & & & & $\begin{array}{l}-0.0180 * \\
(0.00972)\end{array}$ & & & & $\begin{array}{c}0.0101 \\
(0.00809)\end{array}$ \\
\hline Experience & & & & $\begin{array}{c}-0.00269 * * * \\
(0.000244)\end{array}$ & & & & $\begin{array}{c}-0.00498 * * * \\
(0.000226)\end{array}$ \\
\hline
\end{tabular}

This article is protected by copyright. All rights reserved. 


\begin{tabular}{|c|c|c|c|c|c|c|c|c|}
\hline In-degree centrality & & & & $\begin{array}{c}0.307 * * * \\
(0.0226)\end{array}$ & & & & $\begin{array}{c}0.427 * * * \\
(0.0192)\end{array}$ \\
\hline Out-degree centrality & & & & $\begin{array}{c}0.110 * * * \\
(0.0234)\end{array}$ & & & & $\begin{array}{c}-0.00376 \\
(0.0199)\end{array}$ \\
\hline Constant & $\begin{array}{l}1.882 * * * \\
(0.0265) \\
\end{array}$ & $\begin{array}{c}2.101 * * * \\
(0.0300)\end{array}$ & $\begin{array}{l}1.890 * * * \\
(0.0304)\end{array}$ & $\begin{array}{l}1.128 * * * \\
(0.0659) \\
\end{array}$ & $\begin{array}{l}1.759 * * * \\
(0.0233)\end{array}$ & $\begin{array}{l}1.040 * * * \\
(0.0330)\end{array}$ & $\begin{array}{c}1.661 * * * \\
(0.0309)\end{array}$ & $\begin{array}{l}1.162 * * * \\
(0.0589)\end{array}$ \\
\hline Observations & 7,458 & 7,458 & 7,458 & 7,458 & 7,458 & 7,458 & 7,458 & 7,458 \\
\hline Number of users & 1,243 & 1,243 & 1,243 & 1,243 & 1,243 & 1,243 & 1,243 & 1,243 \\
\hline chi-square test & 53.54 & 120.6 & 120.6 & 483.2 & 1133 & 1263 & 1263 & 2268 \\
\hline Prob > chi 2 & 0 & 0 & 0 & 0 & 0 & 0 & 0 & 0 \\
\hline
\end{tabular}


To test $\mathrm{H} 3 \mathrm{a}$, we examined the interaction between self-disclosure and interruptions on content appreciation. Figure 7 shows the results. To create the interaction term, the variables were multiplied. According to Table 4 , the interaction was significant $(\beta=0.0257, p=$ 0.000). A less interruptive interface increased the number of likes given. This increase was more salient for users with a high extent of self-disclose than for those with a low extent of self-disclose. Hence, H3a was supported.

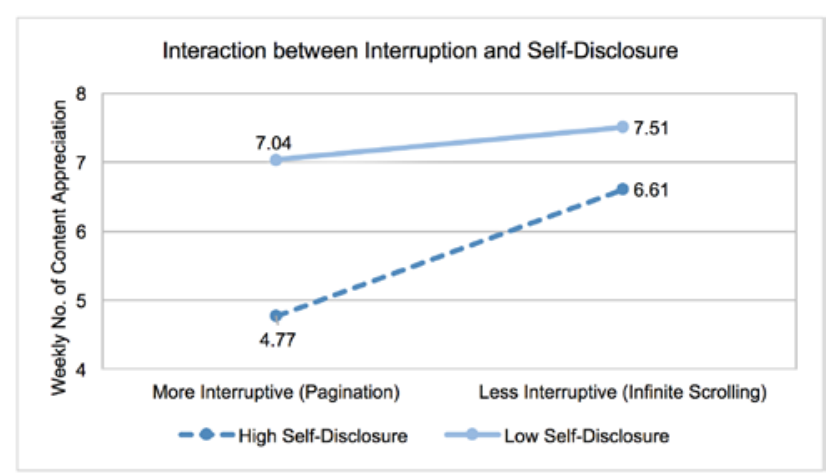

Figure 7: Effect of Interruption and Self-Disclosure on Content Appreciation ${ }^{3}$

Figure 8 shows the results for $\mathrm{H} 3 \mathrm{~b}$. For the number of created posts, the interaction between self-disclosure and interruptions was significant $(\beta=0.0604, p=0.000)$. An interface with more interruptions increased the number of created posts. This increase was less salient for those with a high extent of self-disclosure than for those with a low extent of self-disclosure. Hence, H3b was not supported.

\footnotetext{
${ }^{3}$ In Figure 7, users with a low extent of self-disclosure showed more content appreciation than those with a high extent of self-disclosure did. Based on the results of two t-tests, the difference for pagination (7.04 vs. 4.77, respectively) was significant, but the difference for infinite scrolling (7.51 vs. 6.61, respectively) was nonsignificant. Why did users with a low extent of self-disclosure click more 'likes' on a pagination interface? One possible reason was implementation timing. When Meilishuo started, the site used pagination. At that time, users might not have been familiar with 'tagging', and so users with fewer tags (unexpectedly) gave more 'likes' to others' content.
} 


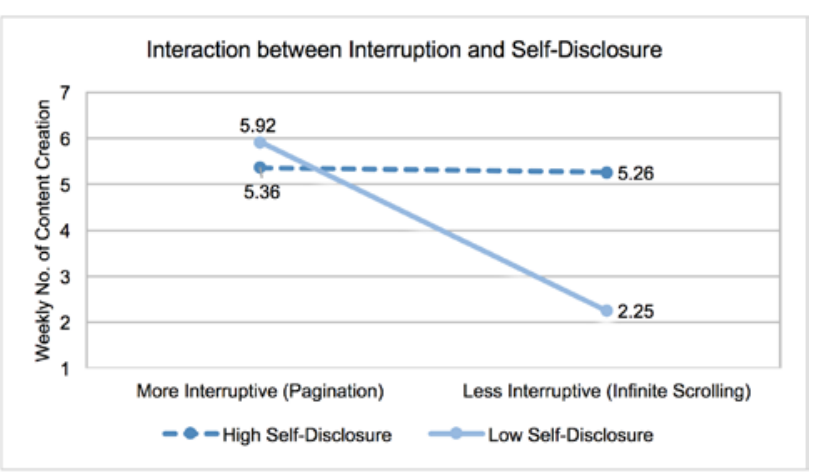

Figure 8: Effect of Interruption and Self-Disclosure on Content Creation

To test $\mathrm{H} 4$, we examined the interaction between out-degree centrality and interruption on the number of likes. Figure 9 presents the interaction. According to Table 4, the positive interaction coefficient $(\beta=0.0291, p=0.018)$ indicates that the increase in content appreciation was greater for users who had high out-degree centrality than for those with low out-degree centrality. Overall, H4 was supported.

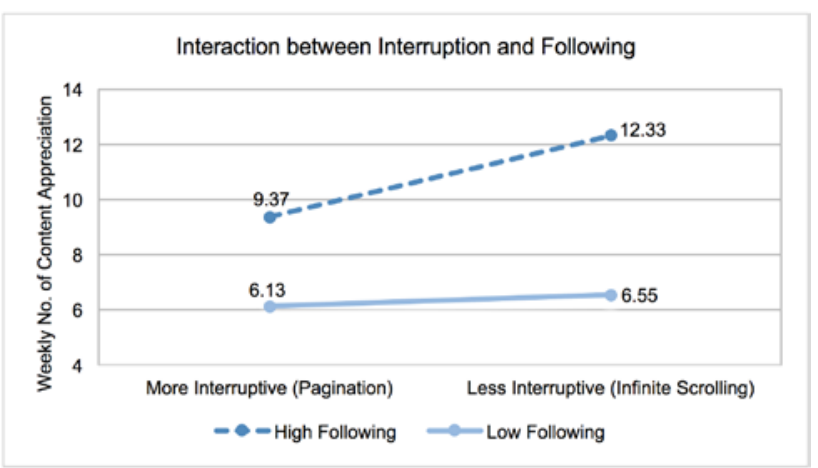

Figure 9. Effect of Interruption and Out-degree Centrality on Content Appreciation

To test H5, we examined the interaction between in-degree centrality and interruptions on content creation. Figure 10 presents the interaction. In Table 4, the positive interaction coefficient $(\beta=0.1189, p=0.000)$ suggests that the decrease in content creation was less salient for users with high in-degree centrality than for those with low in-degree centrality. A closer examination reveals that although users with fewer followers decreased their creation of shared items, users with more followers increased their creation of shared items. The results aligned with our arguments for H5.

This article is protected by copyright. All rights reserved. 


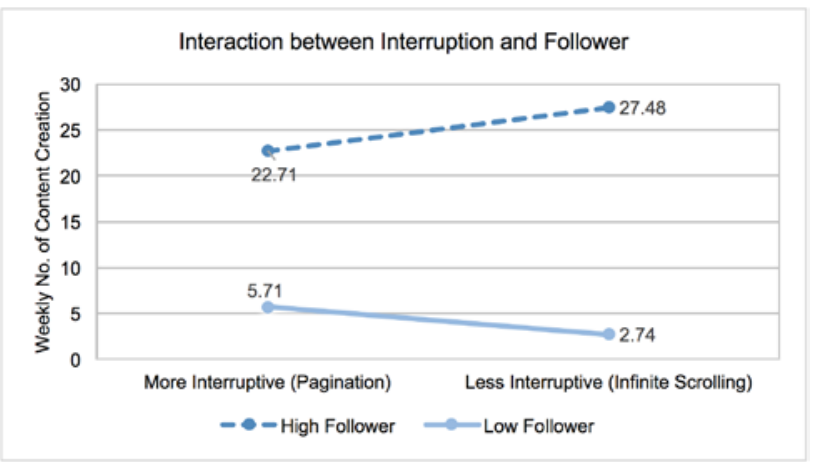

Figure 10. Effect of Interruption and In-degree Centrality on Content Creation

This article is protected by copyright. All rights reserved. 
Table 4. Analysis Results of Moderation Effects

\begin{tabular}{lcccc}
\hline Variables & $(1)$ & $(2)$ & $(3)$ & $(4)$ \\
& Like & Create & Like & Create \\
\hline Interface type & $0.109^{* * *}$ & $-0.793^{* * *}$ & $0.187^{* * *}$ & $-0.753^{* * *}$ \\
& $(0.0315)$ & $(0.0430)$ & $(0.0473)$ & $(0.0539)$ \\
\hline Week dummy & -0.0467 & 0.0286 & $-0.0489^{*}$ & 0.0151 \\
$\left(3^{\text {rd }}\right.$ March $-9^{\text {th }}$ March) & $(0.0287)$ & $(0.0373)$ & $(0.0288)$ & $(0.0372)$ \\
\hline Week dummy & -0.0175 & $0.154^{* * *}$ & -0.0186 & $0.149^{* * *}$ \\
$\left(10^{\text {th }}\right.$ March $-16^{\text {th }}$ March) & $(0.0285)$ & $(0.0371)$ & $(0.0286)$ & $(0.0369)$ \\
\hline Week dummy & $-0.166^{* * *}$ & $0.222^{* * *}$ & $-0.164^{* * *}$ & $0.237^{* * *}$ \\
$\left(31^{\text {st }}\right.$ March $-6^{\text {th }}$ April) & $(0.0284)$ & $(0.0406)$ & $(0.0285)$ & $(0.0407)$ \\
\hline Week dummy & $-0.126^{* * *}$ & $-0.166^{* * *}$ & $-0.123^{* * *}$ & $-0.161^{* * *}$ \\
$\left(7^{\text {th }}\right.$ April $-13^{\text {th }}$ April) & $(0.0283)$ & $(0.0419)$ & $(0.0283)$ & $(0.0420)$ \\
\hline Self-disclosure & $-0.0327^{* * *}$ & $-0.0164 *$ & $-0.0181^{*}$ & 0.00801 \\
& $(0.0104)$ & $(0.00899)$ & $(0.00971)$ & $(0.00814)$ \\
\hline Experience & $-0.00268^{* * *}$ & $-0.00497^{* * *}$ & $-0.00269^{* * *}$ & $-0.00496^{* * *}$ \\
& $(0.000244)$ & $(0.000226)$ & $(0.000244)$ & $(0.000227)$ \\
\hline In-degree centrality & $0.307^{* * *}$ & $0.424 * * *$ & $0.308^{* * *}$ & $0.368^{* * *}$ \\
& $(0.0226)$ & $(0.0192)$ & $(0.0226)$ & $(0.0204)$ \\
\hline Out-degree centrality & $0.110^{* * *}$ & -0.00518 & $0.0950^{* * *}$ & 0.000442 \\
& $(0.0234)$ & $(0.0200)$ & $(0.0242)$ & $(0.0200)$ \\
\hline Interface type $*$ Self-disclosure & $0.0257^{* * *}$ & $0.0604^{* * *}$ & &
\end{tabular}

This article is protected by copyright. All rights reserved. 
(0.0123)

\begin{tabular}{|c|c|c|c|c|}
\hline Interface type $*$ In-degree centrality & & & & $\begin{array}{c}0.1189^{* * *} \\
(0.0150)\end{array}$ \\
\hline Constant & $\begin{array}{c}1.153 * * * \\
(0.0663)\end{array}$ & $\begin{array}{l}1.222 * * * \\
(0.0594)\end{array}$ & $\begin{array}{c}1.174 * * * \\
(0.0686)\end{array}$ & $\begin{array}{l}1.299 * * * \\
(0.0609)\end{array}$ \\
\hline Observations & 7,458 & 7,458 & 7,458 & 7,458 \\
\hline chi-square test & 499.6 & 2307 & 489.9 & 2296 \\
\hline Prob > chi 2 & 0 & 0 & 0 & 0 \\
\hline
\end{tabular}




\section{Discussion and Implications}

\subsection{Key Findings}

Our findings indicate that interruptions exert opposite effects on appreciation of others' content and users' creation of shared content. Specifically, interruptions decrease content appreciation but promote content creation. These contrasting effects point out the importance of differentiating user contribution types. Our findings also show that users' extent to selfdisclose, as well as in-degree and out-degree centrality, moderate the above relationships.

Our study makes several contributions. First, prior studies about user contribution behaviours mainly focus on psychological motivators and user demographics (Cheema \& Kaikati, 2010; Cheung \& Lee, 2012); relatively few studies examine interface features and their effects on user contributions. To address this void, our study examined the effects of interruptions on user contributions and investigated attention trade-off between creating and liking behaviour. Second, despite the wide adoption of infinite scrolling layouts, to our knowledge, our study is the first to theorise that infinite scrolling creates fewer interruptions to users than pagination does; this theory enables us to predict their effects on user contributions. Prior studies examined presentation adaptation of content display on mobile phones (Adipat, Zhang, \& Zhou, 2011), website quality (Wells, Valacich, \& Hess, 2011), designs of filler interfaces (Lee, Chen, \& Ilie, 2012), webpage visual complexity and order (Deng \& Poole, 2010). Adding to these studies, our examination of infinite scrolling further contributes to user interface design research. Third, whilst prior studies discuss user contributions in e-commerce in general, we distinguished between creating shared content and appreciating others' content. As noted, content creation involves cognitive effort, whereas content appreciation involves social relational aspects. The separation of the two user contributions enabled us to reveal how they are differently influenced by interruptions. Finally, using a combination of a lab experiment and a field study enabled us to capture users' behaviours in a controlled environment and in a natural setting. Most previous studies on interfaces used lab experiments only (such as Deng \& Poole, 2010; Lee et al., 2012; Wells et al., 2011). Through lab experiments, although researchers can ask subjects to report their perceptions and intentions to use websites, subjects are aware they are being observed. 
Findings based solely on lab experiments may not reflect real user behaviour. Although sending a survey to users can obtain a large range of respondents (such as Cheung \& Lee, 2012; Ma \& Agarwal, 2007), self-reported data on contribution behaviours can be biased by factors such as social desirability. Our field study addresses these limitations because users were not aware they were being observed by researchers.

\subsection{Theoretical Implications}

Our findings have several theoretical implications. First, to our knowledge, we are the first to examine how interruptions resulting from different interface layouts impact user contributions. Is a less interruptive layout always better? The literature is silent on this. Our study also extends the literature that discusses knowledge contribution (Ma \& Agarwal, 2007; Wasko \& Faraj, 2005), that is, a specific type of content creation on social media. Scholars do recognise that appreciating others' content is an important type of user contribution (Butler et al., 2002) because it is systematic feedback to help the community retain contributors (Moon $\&$ Sproull, 2008). Based on this, we take content appreciation into consideration. Our results demonstrate that an interface feature (interruption, in our case) has a contrasting effect on the two types of user contribution.

Second, whereas prior research tends to theorise user contributions from a social psychological perspective, such as identifying motivational factors (Berger \& Schwartz, 2011; Xia et al., 2012), our study contributes to this body of literature by taking the perspective of attention allocation. Taking a social psychological perspective is proper because social commerce is a network of people, and people's thoughts and behaviours are easily influenced by others. In addition to human factors, technological factors play an important role. Interruption is a common technological feature and we argue that it alters users' attention allocation and guides user contributions. Kahneman (1973) suggested that attention allocation can be involuntary. Even a short pause created by a click in the pagination layout triggers involuntary attention allocation, leading to more content creation. Interestingly, users may not realise that such a mild interruption induces a behavioural change. 
Finally, our study sheds light on the moderating roles of user and network characteristics on the relationship between interruptions and user contributions. Attention is a low-level cognitive resource. Researchers often consider attention to be an instant response with limited cognitive processing, and thus, the possible moderation of user characteristics and stimulus characteristics (i.e., network, in our case) has been neglected. Our study extends the capacity theory of allocation by considering the moderation of extent of self-disclosure, in-degree and out-degree centrality on the relationship between interruption and user contributions. Our findings align with prior research that information-rich networks can drive user contributions (Wu, 2013) and extends the discussions about the importance of social network ties in information exchange (Huang et al., 2017). We demonstrate the need to consider user characteristics and network characteristics in the literature on user contribution.

\subsection{Practical Implications}

Social commerce is a new form of e-commerce. It leverages the increased popularity of social media as a tool for socialisation and information sharing to promote business activities. Despite its increasing importance, practitioners know little about how to promote user contributions, which is critical to the sustainability of their sites. However, 'user contribution' is a general term. Our study informs practitioners that they should separately consider each type of user contribution, because various types of contribution compete for users' cognitive resources. It is important for practitioners to prioritise what user contributions they look for and implement interface design accordingly. One interface feature is the use of interruption. When there are interruptions, users tend to create shared content. In our study, an interruption exists in the form of pagination. The 'design' of interruption is quite natural and it matches real settings. In addition to interruption, practitioners can explore other ways (such as pop-up banners with a short duration) to stimulate users to create more shared content.

Another practical contribution is our examination of the infinite scrolling layout. In our experiment, we used the two layouts (pagination vs. infinite scrolling) to manipulate the degree of interruption. Methodologically, our manipulation is less artificial than online prompting. Practically, our study informs practitioners about the effect of the two layouts on user contributions. In particular, although many social commerce sites have changed their 
design to infinite scrolling, its effects have not been thoroughly investigated. Practitioners have diverse opinions about the effectiveness of infinite scrolling (Corwin, 2013). Dan McKinley, principal engineer at Etsy.com said, 'My point is not that infinite scroll is stupid. It may be great on your website. But we should have done a better job of understanding the people using our website' (McKinley, 2012). To ease such concerns, our findings indicate that the effect of infinite scrolling is mixed. Because infinite scrolling is less interruptive to user navigation, users' content creation decreases. This decrease can be detrimental to those social commerce sites that rely on new product content. Furthermore, since users' attention and cognitive resources are limited, when social commerce sites channel user attention to generate new product content, users may spend less effort in appreciating others' content. That said, practitioners should prioritise their goals and handle this trade-off smartly. To simply attract traffic and increase users' browsing time on the site, a less interruptive interface (such as infinite scrolling) is recommended, as users are more engaged in browsing. To promote content creation, a more interruptive interface (such as pagination) can be helpful, because users are paused and may switch to other cognitive tasks. Social commerce site designers should balance advantages and disadvantages before adopting a certain user interface.

\subsection{Limitations and Future Research}

Our study is not without limitations. First, we should account for individual differences and the natural history attributed to user contributions on social commerce sites. However, since the user characteristics data from Meilishuo is a snapshot, the data does not tell us the evolution of user characteristics. Future research can explore the longitudinal changes in user characteristics and contributions on social commerce sites. Second, our field study data came from Meilishuo, which is dominated by female users. Men and women have different online behaviours (Riedl, Hubert, \& Kenning, 2010). Also, the Meilishuo interface has only a 'like' button; it has no 'dislike' button. Thus, caution is advised in generalising the results of our study to other settings. Third, we conducted both a lab experiment and a field study to examine the effects of interruptions on the two types of user contributions. The two studies complement each other - the findings of the lab experiment indicated high internal validity 
and the findings of the field study indicated high external validity. Despite these strengths, we could not precisely measure attention. In the future, an eye-tracking technique might be used to measure the attention that users pay to a specific post to better capture the way users browse content.

\section{Conclusion}

Our study examines the effects of interruptions on user contributions in social commerce from the perspective of attention allocation. There are two types of user contributions: creating shared content and appreciating others' content. We conducted one lab experiment and one field study to test our hypotheses. Our findings show that interruptions promote content creation but weaken content appreciation. User characteristics moderate these effects. Our findings bring new insights to researchers and practitioners who plan to explore and design effective interfaces to guide user contributions in social commerce.

Acknowledgement: Libo Liu is the corresponding author of this paper. Correspondence concerning this paper should be addressed to Libo Liu (liboliu@swin.edu.au).

This article is protected by copyright. All rights reserved. 


\section{References}

Adipat, B., Zhang, D., \& Zhou, L. (2011). The effects of tree-view based presentation adaptation on mobile web browsing. MIS Quarterly, 35(1), 99-121.

Ayyagari, R., Grover, V., \& Purvis, R. (2011). Technostress: Technological antecedents and implications. MIS Quarterly, 35(4), 831-858.

Baddeley, A. (1992). Working memory. Science, 255(5044), 556-559.

Baecker, R., Booth, K., Jovicic, S., McGrenere, J., \& Moore, G. (2000). Reducing the gap between what users know and what they need to know. In Proceedings of the ACM 2000 International Conference on Intelligent User Interfaces (pp. 17-23). New York: ACM Press

Ballinger, G. A. (2004). Using generalized estimating equations for longitudinal data analysis. Organizational Research Methods, 7(2), 127-150.

Baird, B., Smallwood, J., Mrazek, M. D., Kam, J. W., Franklin, M. S., \& Schooler, J. W. (2012). Inspired by distraction: mind wandering facilitates creative incubation. Psychological Science, 23(10), 1117-1122.

Berger, J., \& Schwartz, E. M. (2011). What drives immediate and ongoing word of mouth? Journal of Marketing Research, 48(5), 869-880.

Brixey, J. J., Robinson, D. J., Johnson, C. W., Johnson, T. R., Turley, J. P., \& Zhang, J. (2007). A concept analysis of the phenomenon interruption. Advances in Nursing Science, 30(1), E26-E42.

Buchanan, T., Paine, C., Joinson, A. N., \& Reips, U. D. (2007). Development of measures of online privacy concern and protection for use on the Internet. Journal of the American Society for Information Science \& Technology, 58(2), 157-165.

Butler, B., Sproull, L., Kiesler, S., \& Kraut, R. (2002). Community effort in online groups: Who does the work and why. In S. Weisband \& L. Atwater (Eds.), Leadership at a distance: Research in technologically supported work. Psychology Press, London, United Kingdom.

Cellier, J.-M., \& Eyrolle, H. (1992). Interference between switched tasks. Ergonomics, 35(1), 25-36.

Chajut, E., \& Algom, D. (2003). Selective attention improves under stress: Implications for theories of social cognition. Journal of Personality and Social Psychology, 85(2), 231-248.

Chan, J. C., Jiang, Z., \& Tan, B. C. (2010). Understanding online interruption-based advertising: Impacts of exposure timing, advertising intent, and brand image. IEEE Transactions on Engineering Management, 57(3), 365-379.

Cheema, A., \& Kaikati, A. M. (2010). The effect of need for uniqueness on word of mouth. Journal of Marketing Research, 47(3), 553-563.

Cheung, C. M., \& Lee, M. K. (2012). What drives consumers to spread electronic word of mouth in online consumer-opinion platforms. Decision Support Systems, 53(1), 218225.

This article is protected by copyright. All rights reserved. 
Cohen, J., Cohen, P., West, S. G., \& Aiken, L. S. (2003). Applied multiple regression/correlation analysis for the behavioral sciences. Hillsdale, NJ: Erlbaum.

Coker, B. L. (2011). Freedom to surf: the positive effects of workplace Internet leisure browsing. New Technology, Work and Employment, 26(3), 238-247.

Corwin, S. (2013). Why pinterest-style infinite-scroll layouts are worthless for everyone except Pinterest. Retrieved from http://stephencorwin.com/blog/?p=97

Csikszentmihalyi, M. (1975). Beyond boredom and anxiety: Experiencing flow in work and play. San Francisco, CA: Jossey-Bass.

Csikszentmihalyi, M., \& Sawyer, R. K. (1995). Creative insight: The social dimension of a solitary moment. In R. J. Sternberg \& J. E. Davidson (Eds.), The nature of insight (pp. 329-363). Cambridge, MA: MIT Press

Dabbish, L., \& Kraut, R. (2008). Research note-awareness displays and social motivation for coordinating communication. Information Systems Research, 19(2), 221-238.

Davenport, T., \& Beck, J. (2001). The attention economy: Understanding the new economy of business. Cambridge, MA: Harvard Business School Press.

Deng, L., \& Poole, M. S. (2010). Affect in web interfaces: A study of the impacts of web page visual complexity and order. MIS Quarterly, 34(4), 711-730.

Elsbach, K. D. (2001). In search of mindless work: Thoughts on job design and the rhythm of managerial thinking. In the annual meeting of the Academy of Management, Washington, DC.

Eriksen, C. W., \& James, J. D. S. (1986). Visual attention within and around the field of focal attention: A zoom lens model. Perception \& Psychophysics, 40(4), 225-240.

Faraj, S., Kudaravalli, S., \& Wasko, M. (2015). Leading collaboration in online communities. MIS Quarterly, 39(2), 393-412.

Faraj, S., Jarvenpaa, S. L., \& Majchrzak, A. (2011). Knowledge collaboration in online communities. Organization Science, 22(5), 1224-1239.

Füller, J., Hutter, K., Hautz, J., \& Matzler, K. (2014). User roles and contributions in innovation-contest communities. Journal of Management Information Systems, 31(1), 273-308.

Gnyawali, D. R., Fan, W., \& Penner, J. (2010). Competitive actions and dynamics in the digital age: An empirical investigation of social networking firms. Information Systems Research, 21(3), 594-613.

Guo, Y. M., \& Poole, M. S. (2009). Antecedents of flow in online shopping: A test of alternative models. Information Systems Journal, 19(4), 369-390.

Hansen, M. T., \& Haas, M. R. (2001). Competing for attention in knowledge markets: Electronic document dissemination in a management consulting company. Administrative Science Quarterly, 46(1), 1-28.

Harrison, D. A., \& Hulin, C. L. (1989). Investigations of absenteeism: Using event history models to study the absence-taking process. Journal of Applied Psychology, 74(2), 300-316.

This article is protected by copyright. All rights reserved. 
Healey, A. N., Sevdalis, N., \& Vincent, C. A. (2006). Measuring intra-operative interference from distraction and interruption observed in the operating theatre. Ergonomics, 49(56), 589-604.

Hennig

of

themselves on the Internet? Journal of Interactive Marketing, 18(1), 38-52.

Hess, T., Fuller, M., \& Campbell, D. (2009). Designing interfaces with social presence:

Using vividness and extraversion to create social recommendation agents. Journal of the Association for Information Systems, 10(12), 889-919

Hong, W., Thong, J. Y., \& Tam, K. Y. (2004a). Designing product listing pages on ecommerce websites: An examination of presentation mode and information format. International Journal of Human-Computer Studies, 61(4), 481-503.

Hong, W., Thong, J. Y., \& Tam, K. Y. (2004b). Does animation attract online users' attention? The effects of flash on information search performance and perceptions. Information Systems Research, 15(1), 60-86.

Hong, W., Thong, J. Y., \& Tam, K. Y. (2004c). The effects of information format and shopping task on consumers' online shopping behavior: A cognitive fit perspective. Journal of Management Information Systems, 21(3), 149-184.

Hsieh, Y.-C., \& Chen, K.-H. (2011). How different information types affect viewer's attention on internet advertising. Computers in Human Behavior, 27(2), 935-945.

Huang, Q., Chen, X., Ou, C. X., Davison, R. M., \& Hua, Z. (2017). Understanding buyers' loyalty to a $\mathrm{C} 2 \mathrm{C}$ platform: The roles of social capital, satisfaction and perceived effectiveness of $\mathrm{e}$

Hofonmmerioe ifistitumtiodralımedhanisms. 27(1), 91-119.

Iqbal, S. T., \& Bailey, B. P. (2010). Oasis: A framework for linking notification delivery to the perceptual structure of goal-directed tasks. ACM Transactions on ComputerHuman Interaction, 17(4), 1-28.

Jett, Q. R., \& George, J. M. (2003). Work interrupted: A closer look at the role of interruptions in organizational life. Academy of management Review, 28(3), 494-507.

Jenkins, J. L., Anderson, B. B., Vance, A., Kirwan, C. B., \& Eargle, D. (2016). More harm than good? How messages that interrupt can make us vulnerable. Information Systems Research, 27(4), 880-896.

Jiang, Z., \& Benbasat, I. (2004). Virtual product experience: Effects of visual and functional control of products on perceived diagnosticity and flow in electronic shopping. Journal of Management Information Systems, 21(3), 111-147.

Jiang, Z., \& Benbasat, I. (2007). The effects of presentation formats and task complexity on online consumers' product understanding. MIS Quarterly, 31(3), 475-500.

Jin, J., \& Dabbish, L.A. Self-interruption on the computer: A typology of discretionary task interleaving, In Proceedings of the 27th International conference on Human Factors in Computing systems, 2009, 1799-1808.

This article is protected by copyright. All rights reserved. 
Kane, G. C., Alavi, M., Labianca, G., \& Borgatti, S. P. (2014). What's different about social media networks? A framework and research agenda. MIS Quarterly, 38, 275-304.

Kahneman, D. (1973). Attention and effort. Prentice-Hall, New Jersey.

Kamis, A., Koufaris, M., \& Stern, T. (2008). Using an attribute-based decision support system for user-customized products online: An experimental investigation. MIS Quarterly, 32(1), 159-177.

Kassim, E. S., Othman, A. K., \& Zamzuri, N. H. (2016). Strategies for sustainable social commerce: The roles of customer focus, innovative business model, legality and trust. Information, 19(7), 2907-2912.

Kelleher, C., \& Helkkula, A. (2010). Virtually speaking-customer to customer communication in blogs. Journal of Applied Management \& Entrepreneurship, 15(3), $4-17$.

Kuisma, J., Simola, J., Uusitalo, L., \& Öörni, A. (2010). The effects of animation and format on the perception and memory of online advertising. Journal of Interactive Marketing, 24(4), 269-282.

Laudon, K. C., \& Traver, C. G. (2009). E-commerce business models and concepts. In K. Laudon (Eds.), E-commerce: Business, technology, society. (pp. 58-85). Upper Saddle River, NJ: Prentice Hall.

Lee, D. H., Im, S., \& Taylor, C. R. (2008). Voluntary self Internet: A multimethod study of the motivations and consequences of disclosing information on blogs. Psychology \& Marketing, 25(7), 692-710.

Lee, M., Cheung, C., Lim, K., \& Sia, C. (2006). Understanding customer knowledge sharing in web-based discussion boards: An exploratory study. Internet Research, 16(3), 289303.

Lee, Y., Chen, A. N., \& Ilie, V. (2012). Can online wait be managed? The effect of filler interfaces and presentation modes on perceived waiting time online. MIS Quarterly, 36(2), 365-394.

Lee, Y. E., \& Benbasat, I. (2003). Interface design for mobile commerce. Communications of the ACM, 46(12), 48-52.

Liang, K. Y., \& Zeger, S. L. (1986). Longitudinal data analysis using generalized linear models. Biometrika, 73(1), 13-22.

Liang, T.-P., \& Turban, E. (2011). Introduction to the special issue social commerce: A research framework for social commerce. International Journal of Electronic Commerce, 16(2), 5-14.

Lohse, G. L., \& Spiller, P. (1998). Electronic shopping. Communications of the ACM, 41(7), $81-87$.

Loranger, H. (2014). Infinite scrolling is not for every website. Nielsen Norman Group. Online available: https://www.nngroup.com/articles/infinite-scrolling/. Retrieved on 11 August 2018.

This article is protected by copyright. All rights reserved. 
Ma, M., \& Agarwal, R. (2007). Through a glass darkly: Information technology design, identity verification, and knowledge contribution in online communities. Information Systems Research, 18(1), 42-67.

Mayer, R. E., \& Moreno, R. (2002). Aids to computer-based multimedia learning. Learning \& Instruction, 12(1), 107-119.

McCoy, S., Everard, A., \& Loiacono, E. T. (2009). Online ads in familiar and unfamiliar sites: Effects on perceived website quality and intention to reuse. Information Systems Journal, 19(4), 437-458.

McKinley, D. (2012). Why did infinite scroll fail at Etsy? Retrieved from http://danwin.com/tag/etsy/.

Moon, J. Y., \& Sproull, L. S. (2008). The role of feedback in managing the Internet-based volunteer work force. Information Systems Research, 19(4), 494-515.

Morris, M. G., \& Venkatesh, V. (2010). Job characteristics and job satisfaction: Understanding the role of enterprise resource planning system implementation. MIS Quarterly, 34(1), 143-161.

Mossholder, K. W., Settoon, R. P., \& Henagan, S. C. (2005). A relational perspective on turnover: Examining structural, attitudinal, and behavioral predictors. Academy of Management Journal, 48(4), 607-618.

Muller, D., Judd, C. M., \& Yzerbyt, V. Y. (2005). When moderation is mediated and mediation is moderated. Journal of Personality and Social Psychology, 89(6), 852863.

Nah, F. F.-H., Eschenbrenner, B., \& DeWester, D. (2011). Enhancing brand equity through flow and telepresence: A comparison of 2D and 3D virtual worlds. MIS Quarterly, 35(3), 731-747.

Murata, K. (1994). Intrusive or co-operative? A cross-cultural study of interruption. Journal of Pragmatics, 21(4), 385-400.

Norman, D. A., \& Bobrow, D. G. (1975). On data-limited and resource-limited processes. Cognitive Psychology, 7(1), 44-64.

O'Reilly, K., \& Marx, S. (2011). How young, technical consumers assess online WOM credibility. Qualitative Market Research, 14(4), 330-359.

Olbrich, R., \& Holsing, C. (2011). Modeling consumer purchasing behavior in social shopping communities with clickstream data. International Journal of Electronic Commerce, 16(2), 15-40.

Palka, W., Pousttchi, K., \& Wiedemann, D. G. (2009). Mobile word-of-mouth: A grounded theory of mobile viral marketing. Journal of Information Technology, 24(2), 172-185.

Palmer, J. W. (2002). Web site usability, design, and performance metrics. Information Systems Research, 13(2), 151-167.

Parboteeah, D. V., Valacich, J. S., \& Wells, J. D. (2009). The influence of website characteristics on a consumer's urge to buy impulsively. Information Systems Research, 20(1), 60-78. 
Parnin, C., \& Rugaber, S. (2011). Resumption strategies for interrupted programming tasks. Software Quality Journal, 19(1), 5-34.

Peng, G., \& Dey, D. (2013). A Dynamic View of the Impact of Network Structure on Technology Adoption: The Case of OSS Development. Information Systems Research, 24(4), 1087-1099.

Persoon, M. C., Broos, H. J., Witjes, J. A., Hendrikx, A. J., \& Scherpbier, A. J. (2011). The effect of distractions in the operating room during endourological procedures. Surgical Endoscopy, 25(2), 437-443.

Rabe-Hesketh, S., \& Skrondal, A. (2008). Multilevel and longitudinal modeling using Stata. STATA Press, College Station, Texas.

Reinecke, K., \& Bernstein, A. (2013). Knowing what a user likes: A design science approach to interfaces that automatically adapt to culture. MIS Quarterly, 37(2), 427-453.

Ren, Y., Kiesler, S., \& Fussell, S. R. (2008). Multiple group coordination in complex and dynamic task environments: Interruptions, coping mechanisms, and technology recommendations. Journal of Management Information Systems, 25(1), 105-130.

Riedl, R., Hubert, M., \& Kenning, P. (2010). Are there neural gender differences in online trust? An fMRI study on the perceived trustworthiness of eBay offers. MIS Quarterly, 34(2), 397-428.

Ritter, S. M., \& Dijksterhuis, A. (2014). Creativity-the unconscious foundations of the incubation period. Frontiers in Human Neuroscience, 8(215), 1-8.

Sandars, J., \& Walsh, K. (2009). The use of online word of mouth opinion in online learning: A questionnaire survey. Medical Teacher, 31(4), 325-327.

Schiffman, N., \& Griest-Bousquet, S. (1992). Optimal shopping performance under graphic and numeric CRT formatting. Human Factors, 27(4), 433-444.

Scott, J. (2000). Social Network Analysis: A Handbook. Sage Publications, London.

Shen, W., Hu, Y. J., \& Rees, J. (2015). Competing for attention: An empirical study of online reviewers' strategic behaviors. MIS Quarterly, 39(3), 683-696.

Speier, C., Vessey, I., \& Valacich, J. S. (2003). The effects of interruptions, task complexity, and information presentation on computer-supported decisionmaking performance. Decision Sciences, 34(4), 771-797.

Stephen, A. T., \& Toubia, O. (2010). Deriving value from social commerce networks. Journal of Marketing Research, 47(2), 215-228.

Straub, D., Limayem, M., \& Karahanna-Evaristo, E. (1995). Measuring system usage: Implications for IS theory testing. Management Science, 41(8), 1328-1342.

Suh, K.-S., \& Lee, Y. E. (2005). The effects of virtual reality on consumer learning: An empirical investigation. MIS Quarterly, 29(4), 673-697.

Tarafdar, M., Tu, Q., \& Ragu-Nathan, T. (2010). Impact of technostress on end-user satisfaction and performance. Journal of Management Information Systems, 27(3), 303-334. 
Tarmizi, R. A., \& Sweller, J. (1988). Guidance during mathematical problem solving. Journal of Educational Psychology, 80(4), 424-436.

Turban, E., Whiteside, J., King, D., \& Outland, J. (2017). Introduction to electronic commerce and social commerce. Springer, New York.

Wang, C., \& Zhang, P. (2012). The evolution of social commerce: The people, management, technology, and information dimensions. Communications of the Association for Information Systems, 31(5). 105-127

Wang, Y. (2016). The study on model transformation from traditional business to ecommerce. Management \& Engineering, 23, 103-109.

Wasko, M. M., \& Faraj, S. (2005). Why should I share? Examining social capital and knowledge contribution in electronic networks of practice. MIS Quarterly, 29(1), 3557.

Wells, J. D., Fuerst, W. L., \& Palmer, J. W. (2005). Designing consumer interfaces for experiential tasks: An empirical investigation. European Journal of Information Systems, 14(3), 273-287.

Wells, J. D., Valacich, J. S., \& Hess, T. J. (2011). What signals are you sending? How website quality influences perceptions of product quality and purchase intentions. MIS Quarterly, 35(2), 373-396.

$\mathrm{Wu}, \mathrm{L}$. (2013) Social network effects on productivity and job security: evidence from the adoption of a social networking tool. Information Sysems Research, 24(1), 30-51.

Wu, W. Y., \& Sukoco, B. M. (2010). Why should I share? Examining consumers' motives and trust on knowledge sharing. Journal of Computer Information Systems, 50(4), 1119.

Xia, M., Huang, Y., Duan, W., \& Whinston, A. B. (2012). To continue sharing or not to continue sharing? An empirical analysis of user decision in peer-to-peer sharing networks. Information Systems Research, 23(1), 247-259.

Zeger, S. L., \& Liang, K.-Y. (1986). Longitudinal data analysis for discrete and continuous outcomes. Biometrics, 42(1), 121-130.

Zeger, S. L., Liang, K.-Y., \& Albert, P. S. (1988). Models for longitudinal data: A generalized estimating equation approach. Biometrics, 44(4), 1049-1060.

Zhang, P. (2000). The effects of animation on information seeking performance on the World Wide Web: Securing attention or interfering with primary tasks? Journal of the Association for Information Systems, 1(1), 1-28.

Zhang, P. (2006). Pop-up animations: Impacts and implications for website design and online advertising. In D. Galletta \& P. Zhang (Eds.), Human-computer interaction and management information systems: Applications Advances in Management Information Systems, vol. 6. Armonk, NY: M.E. Sharpe, 2006, pp. 70-97.

This article is protected by copyright. All rights reserved. 


\section{Appendix 1: Summary of Studies Related to User Contributions in Social Commerce Settings}

\begin{tabular}{|c|c|c|c|c|}
\hline Author (Year) & $\begin{array}{l}\text { Theoretical } \\
\text { Background }\end{array}$ & Factors/Antecedent & Data Collection & Variables of Interest \\
\hline $\begin{array}{l}\text { Berger and Schwartz } \\
(2011)\end{array}$ & Motivation theory & $\mathrm{N} / \mathrm{A}$ & $\begin{array}{l}\text { Quantitative (field } \\
\text { experiment using } \\
\text { secondary data) }\end{array}$ & $\begin{array}{l}\text { Existing and } \\
\text { progressing word of } \\
\text { mouth (WOM) }\end{array}$ \\
\hline $\begin{array}{l}\text { Cheema and Kaikati } \\
\text { (2010) }\end{array}$ & $\begin{array}{l}\text { Social exchange } \\
\text { theory }\end{array}$ & $\begin{array}{l}\text { Need for uniqueness; fast-moving } \\
\text { consumer foods }\end{array}$ & $\begin{array}{l}\text { Quantitative } \\
\text { (survey with } \\
\text { experimental } \\
\text { design) }\end{array}$ & Positive WOM \\
\hline $\begin{array}{l}\text { Cheung and Lee } \\
\text { (2012) }\end{array}$ & $\begin{array}{l}\text { Social exchange } \\
\text { theory, social } \\
\text { identity theory, } \\
\text { social cognitive } \\
\text { theory }\end{array}$ & $\begin{array}{l}\text { Egoism (reputation and reciprocity), } \\
\text { collectivism (sense of belonging), altruism } \\
\text { (enjoyment in helping others), } \\
\text { participation (moral obligation), } \\
\text { knowledge self-efficacy }\end{array}$ & $\begin{array}{l}\text { Quantitative } \\
\text { (survey) }\end{array}$ & WOM intention \\
\hline $\begin{array}{l}\text { Füller, Hutter, Hautz, } \\
\text { and Matzler (2014) }\end{array}$ & $\begin{array}{l}\text { Social network } \\
\text { theory }\end{array}$ & Social structure & $\begin{array}{l}\text { Quantitative (field } \\
\text { study using } \\
\text { secondary data) }\end{array}$ & User contribution \\
\hline $\begin{array}{l}\text { Hennig-Thurau et al. } \\
\text { (2004) }\end{array}$ & Motivation theory & $\begin{array}{l}\text { Customer support for platform, expressing } \\
\text { negative feelings, concerns associated with } \\
\text { other customers, positive self- } \\
\text { enhancement, social benefit, economic } \\
\text { incentives, helping the firm, seeking } \\
\text { advice }\end{array}$ & $\begin{array}{l}\text { Quantitative } \\
\text { (survey) }\end{array}$ & eWOM behaviour \\
\hline
\end{tabular}

This article is protected by copyright. All rights reserved. 


\begin{tabular}{|c|c|c|c|c|}
\hline Author (Year) & $\begin{array}{l}\text { Theoretical } \\
\text { Background }\end{array}$ & Factors/Antecedent & Data Collection & Variables of Interest \\
\hline $\begin{array}{l}\text { Kelleher and } \\
\text { Helkkula (2010) }\end{array}$ & & $\begin{array}{l}\text { Beneficiary's knowledge, expert } \\
\text { (dis)passionate beneficiary, novice } \\
\text { (dis)passionate beneficiary }\end{array}$ & $\begin{array}{l}\text { Qualitative } \\
\text { (narrative analysis) }\end{array}$ & $\begin{array}{l}\text { eWOM behaviour in } \\
\text { online blogs }\end{array}$ \\
\hline $\begin{array}{l}\text { Lee, Cheung, Lim, } \\
\text { and Sia (2006) }\end{array}$ & $\begin{array}{l}\text { Social exchange } \\
\text { theory }\end{array}$ & $\begin{array}{l}\text { Individual interest, social context, } \\
\text { technological attributes }\end{array}$ & $\begin{array}{l}\text { Quantitative } \\
\text { (survey) }\end{array}$ & $\begin{array}{l}\text { Knowledge sharing } \\
\text { between customers in } \\
\text { web-based discussion } \\
\text { boards }\end{array}$ \\
\hline $\begin{array}{l}\text { O'Reilly and Marx } \\
\text { (2011) }\end{array}$ & Grounded theory & $\begin{array}{l}\text { Self-worth, risk averseness, enactment of } \\
\text { negativity bias }\end{array}$ & $\begin{array}{l}\text { Qualitative } \\
\text { (interviews) }\end{array}$ & $\begin{array}{l}\text { Making and taking } \\
\text { eWOM }\end{array}$ \\
\hline $\begin{array}{l}\text { Palka, Pousttchi, and } \\
\text { Wiedemann (2009) }\end{array}$ & Grounded theory & $\begin{array}{l}\text { Social-based conditions, resource-based } \\
\text { conditions, consumption-based conditions, } \\
\text { attitude-based conditions, individual-based } \\
\text { conditions }\end{array}$ & $\begin{array}{l}\text { Qualitative } \\
\text { (interviews) }\end{array}$ & Mobile WOM \\
\hline $\begin{array}{l}\text { Sandars and Walsh } \\
(2009)\end{array}$ & & $\begin{array}{l}\text { Helping other users, influencing authors of } \\
\text { a module, developing e-community for } \\
\text { learners }\end{array}$ & $\begin{array}{l}\text { Quantitative } \\
\text { (survey) }\end{array}$ & $\begin{array}{l}\text { Online WOM opinion } \\
\text { (user feedback) }\end{array}$ \\
\hline $\begin{array}{l}\text { Xia, Huang, Duan, } \\
\text { and Whinston (2012) }\end{array}$ & Reciprocity & $\begin{array}{l}\text { Receiving from a network, providing to a } \\
\text { network }\end{array}$ & $\begin{array}{l}\text { Quantitative (field } \\
\text { study using panel } \\
\text { data) }\end{array}$ & $\begin{array}{l}\text { Users' continued- } \\
\text { sharing behaviour }\end{array}$ \\
\hline $\begin{array}{l}\text { Wu and Sukoco } \\
(2010)\end{array}$ & Motivation theory & $\begin{array}{l}\text { Achievement-based motive, affiliation- } \\
\text { based motive, power-based motive }\end{array}$ & $\begin{array}{l}\text { Quantitative } \\
\text { (survey) }\end{array}$ & Knowledge sharing \\
\hline
\end{tabular}

This article is protected by copyright. All rights reserved. 
Appendix 2: Summary of Studies Related to Interface Design

\begin{tabular}{|c|c|c|c|c|c|}
\hline Study & Object of Study & Theory & Factors & Method & Key Findings \\
\hline $\begin{array}{l}\text { Adipat et } \\
\text { al. (2011) }\end{array}$ & $\begin{array}{l}\text { Examining the } \\
\text { effects of different } \\
\text { presentation } \\
\text { adaptation on } \\
\text { mobile web } \\
\text { browsing }\end{array}$ & $\begin{array}{l}\text { Cognitive fit } \\
\text { theory, } \\
\text { information } \\
\text { foraging } \\
\text { theory }\end{array}$ & n.a. & Experiment & $\begin{array}{l}\text { Content presentation adaptation significantly improves } \\
\text { user performance and perception in mobile web browsing. } \\
\text { The complexity of an information search task moderates } \\
\text { the positive effect of presentation adaptation on user } \\
\text { performance and perception. }\end{array}$ \\
\hline $\begin{array}{l}\text { Dabbish } \\
\text { and Kraut } \\
(2008)\end{array}$ & $\begin{array}{l}\text { Examining the } \\
\text { utility of awareness } \\
\text { displays for } \\
\text { coordinating } \\
\text { communication } \\
\text { interactions }\end{array}$ & n.a & $\begin{array}{l}\text { Awareness } \\
\text { displays }\end{array}$ & Experiment & $\begin{array}{l}\text { Awareness displays lead to communication attempts that } \\
\text { are less disruptive. } \\
\text { Displays with an abstract representation of a } \\
\text { collaborator's workload lead to better timing of } \\
\text { interruptions without overwhelming the person viewing } \\
\text { the display. }\end{array}$ \\
\hline $\begin{array}{l}\text { Deng and } \\
\text { Poole } \\
(2010)\end{array}$ & $\begin{array}{l}\text { Examining the role } \\
\text { of visual complexity } \\
\text { and order in the } \\
\text { design of webpages } \\
\text { that enhance users' } \\
\text { positive emotional } \\
\text { reactions and } \\
\text { facilitate desirable } \\
\text { psychological states } \\
\text { and behaviours }\end{array}$ & $\begin{array}{l}\text { Environmen } \\
\text { tal } \\
\text { psychology } \\
\text { model, } \\
\text { reversal } \\
\text { theory, } \\
\text { cognitive } \\
\text { appraisal } \\
\text { theories }\end{array}$ & $\begin{array}{l}\text { Visual } \\
\text { complexity } \\
\text { and order } \\
\text { design }\end{array}$ & Experiment & $\begin{array}{l}\text { Users' initial emotional responses evoked by the visual } \\
\text { complexity and order design features of a webpage when } \\
\text { first encountered. } \\
\text { Users' initial emotional responses will have carry-over } \\
\text { effects on subsequent approach behaviour toward the } \\
\text { website. } \\
\text { Webpage visual complexity and order influence users' } \\
\text { emotions and behaviours are different when users are in } \\
\text { different meta-motivational states. }\end{array}$ \\
\hline
\end{tabular}

This article is protected by copyright. All rights reserved. 


\begin{tabular}{|c|c|c|c|c|c|}
\hline Study & Object of Study & Theory & Factors & Method & Key Findings \\
\hline $\begin{array}{l}\text { Guo and } \\
\text { Poole } \\
(2009)\end{array}$ & $\begin{array}{l}\text { Investigating the } \\
\text { complete structure } \\
\text { of the flow model in } \\
\text { online shopping } \\
\text { context }\end{array}$ & Flow theory & n.a. & Survey & $\begin{array}{l}\text { Website complexity affects flow via the mediating effects } \\
\text { of the three preconditions of flow. }\end{array}$ \\
\hline $\begin{array}{l}\text { Hess, } \\
\text { Fuller, and } \\
\text { Campbell } \\
(2009)\end{array}$ & $\begin{array}{l}\text { Investigating how } \\
\text { the recommendation } \\
\text { agent's extraversion } \\
\text { and vividness } \\
\text { influence users' } \\
\text { perception of social } \\
\text { presence and trust }\end{array}$ & $\begin{array}{l}\text { Social } \\
\text { presence }\end{array}$ & $\begin{array}{l}\text { Extraversi } \\
\text { on, } \\
\text { vividness, } \\
\text { computer } \\
\text { playfulness }\end{array}$ & Experiment & $\begin{array}{l}\text { Recommendation agent's extraversion personality and } \\
\text { vividness increase users' perceptions of social presence. } \\
\text { Vividness also positively moderates the relationship } \\
\text { between extraversion and social presence. }\end{array}$ \\
\hline $\begin{array}{l}\text { Hong, } \\
\text { Thong, and } \\
\text { Tam } \\
(2004 b)\end{array}$ & $\begin{array}{l}\text { Investigating the } \\
\text { effects of flash on } \\
\text { information search } \\
\text { performance and } \\
\text { perceptions }\end{array}$ & $\begin{array}{l}\text { Central } \\
\text { capacity } \\
\text { theory, } \\
\text { attention } \\
\text { theory }\end{array}$ & $\begin{array}{l}\text { Flash, task } \\
\text { relevant }\end{array}$ & Experiment & $\begin{array}{l}\text { Flash attracts users' attention and has negative effects on } \\
\text { users' focused attention and attitude to website. }\end{array}$ \\
\hline $\begin{array}{l}\text { Hong, } \\
\text { Thong, and } \\
\text { Tam } \\
(2004 \mathrm{c})\end{array}$ & $\begin{array}{l}\text { Investigating the fit } \\
\text { between information } \\
\text { format and shopping } \\
\text { task and examining } \\
\text { its influence on } \\
\text { consumers' } \\
\text { shopping } \\
\text { performance and }\end{array}$ & $\begin{array}{l}\text { Cognitive fit } \\
\text { theory, } \\
\text { attention } \\
\text { theory }\end{array}$ & $\begin{array}{l}\text { Informatio } \\
\mathrm{n} \text { format, } \\
\text { shopping } \\
\text { task }\end{array}$ & Experiment & $\begin{array}{l}\text { Matching between the information format and the } \\
\text { shopping task helps consumers search efficiently and have } \\
\text { better product information. }\end{array}$ \\
\hline
\end{tabular}

This article is protected by copyright. All rights reserved. 


\begin{tabular}{|c|c|c|c|c|c|}
\hline Study & Object of Study & Theory & Factors & Method & Key Findings \\
\hline & experience & & & & \\
\hline $\begin{array}{l}\text { Jiang and } \\
\text { Benbasat } \\
(2004)\end{array}$ & $\begin{array}{l}\text { Identifying two } \\
\text { types of virtual } \\
\text { product experience } \\
\text { technology: visual } \\
\text { control and } \\
\text { functional control }\end{array}$ & Flow theory & $\begin{array}{l}\text { Virtual } \\
\text { product } \\
\text { experience }\end{array}$ & Experiment & $\begin{array}{l}\text { Visual and functional control increases perceived } \\
\text { diagnosticity. } \\
\text { Visual and functional control increases consumers' overall } \\
\text { perceived diagnosticity and flow. }\end{array}$ \\
\hline $\begin{array}{l}\text { Jiang and } \\
\text { Benbasat } \\
(2007)\end{array}$ & $\begin{array}{l}\text { Identifying the } \\
\text { antecedents and } \\
\text { consequences of } \\
\text { website aesthetics }\end{array}$ & $\begin{array}{l}\text { Aesthetic } \\
\text { design }\end{array}$ & $\begin{array}{l}\text { Website } \\
\text { aesthetics }\end{array}$ & $\begin{array}{l}\text { Card sorting } \\
\text { and survey }\end{array}$ & $\begin{array}{l}\text { Website aesthetics can be influenced by five design } \\
\text { elements: unity, complexity, intensity, novelty, and } \\
\text { interactivity. Users' perceptions of website aesthetics } \\
\text { influence perceived utility and their attitudes toward the } \\
\text { website. }\end{array}$ \\
\hline $\begin{array}{l}\text { Kamis, } \\
\text { Koufaris, } \\
\text { and Stern } \\
(2008)\end{array}$ & $\begin{array}{l}\text { Examining the } \\
\text { mediating role of } \\
\text { decision process } \\
\text { variables in online } \\
\text { customer decision } \\
\text { support systems }\end{array}$ & $\begin{array}{l}\text { Cognitive fit } \\
\text { theory, flow } \\
\text { theory }\end{array}$ & $\begin{array}{l}\text { Attribute- } \\
\text { based } \\
\text { interface } \\
\text { design, } \\
\text { alternative- } \\
\text { based } \\
\text { interface } \\
\text { design, } \\
\text { task } \\
\text { complexity }\end{array}$ & Experiment & $\begin{array}{l}\text { Effect of decision support system interface design on } \\
\text { behavioural intentions is mediated by perceived usefulness } \\
\text { and perceived enjoyment. } \\
\text { Users of an attribute-based DSS perceive higher } \\
\text { usefulness and enjoyment than users of an alternative- } \\
\text { based one. } \\
\text { Users of the alternative-based DSS perceive ease of use } \\
\text { and control decrease as task complexity increases. }\end{array}$ \\
\hline $\begin{array}{l}\text { Lee et al. } \\
(2012)\end{array}$ & $\begin{array}{l}\text { Investigating the } \\
\text { effects of the } \\
\text { presence and various }\end{array}$ & $\begin{array}{l}\text { Resource } \\
\text { allocation } \\
\text { theory, }\end{array}$ & $\begin{array}{l}\text { Temporal } \\
\text { dissociatio } \\
\mathrm{n} \text { focused }\end{array}$ & Experiment & $\begin{array}{l}\text { Filler interface is important to manipulate online users' } \\
\text { cognitive time perceptions. }\end{array}$ \\
\hline
\end{tabular}

This article is protected by copyright. All rights reserved. 


\begin{tabular}{|c|c|c|c|c|c|}
\hline Study & Object of Study & Theory & Factors & Method & Key Findings \\
\hline & $\begin{array}{l}\text { designs of filler } \\
\text { interfaces on } \\
\text { cognitive absorption } \\
\text { factors }\end{array}$ & $\begin{array}{l}\text { cognitive } \\
\text { absorption } \\
\text { theory, } \\
\text { human } \\
\text { computer } \\
\text { interaction } \\
\text { theories }\end{array}$ & $\begin{array}{l}\text { immersion, } \\
\text { heightened } \\
\text { enjoyment }\end{array}$ & & \\
\hline $\begin{array}{l}\text { Palmer } \\
(2002)\end{array}$ & $\begin{array}{l}\text { Developing and } \\
\text { validating website } \\
\text { usability, design and } \\
\text { performance metrics }\end{array}$ & $\begin{array}{l}\text { Media } \\
\text { richness } \\
\text { theory }\end{array}$ & n.a. & Panel data & $\begin{array}{l}\text { Website success is associated with website download } \\
\text { delay, navigation, interactivity, and responsiveness. }\end{array}$ \\
\hline $\begin{array}{l}\text { Parboteeah } \\
\text {, Valacich, } \\
\text { and Wells } \\
(2009)\end{array}$ & $\begin{array}{l}\text { Investigating how e- } \\
\text { commerce website } \\
\text { task-relevant cues } \\
\text { and mood-relevant } \\
\text { cues influence } \\
\text { impulsive buying }\end{array}$ & $\begin{array}{l}\text { Environmen } \\
\text { tal stimuli }\end{array}$ & $\begin{array}{l}\text { Task- } \\
\text { relevant } \\
\text { cues, } \\
\text { mood- } \\
\text { relevant } \\
\text { cues }\end{array}$ & Experiment & $\begin{array}{l}\text { Impulsive behaviour is maximized when positive } \\
\text { cognitive reactions and affective reactions are } \\
\text { simultaneously maximized by providing high-quality task- } \\
\text { relevant cues and mood-relevant cues, such as visual } \\
\text { appeal. }\end{array}$ \\
\hline $\begin{array}{l}\text { Reinecke } \\
\text { and } \\
\text { Bernstein } \\
(2013)\end{array}$ & $\begin{array}{l}\text { Investigating how } \\
\text { culturally adaptive } \\
\text { systems influence } \\
\text { user interface } \\
\text { preferences }\end{array}$ & n.a & $\begin{array}{l}\text { Cultural } \\
\text { backgroun } \\
\text { d }\end{array}$ & Field study & $\begin{array}{l}\text { An efficient method cultural additivity to design interface } \\
\text { and adapt their look and feel to suit visual preferences }\end{array}$ \\
\hline
\end{tabular}

This article is protected by copyright. All rights reserved. 


\begin{tabular}{|c|c|c|c|c|c|}
\hline Study & Object of Study & Theory & Factors & Method & Key Findings \\
\hline $\begin{array}{l}\text { Suh and } \\
\text { Lee }(2005)\end{array}$ & $\begin{array}{l}\text { Investigating the } \\
\text { role of virtual reality } \\
\text { in consumer } \\
\text { learning about } \\
\text { products }\end{array}$ & $\begin{array}{l}\text { Theory of } \\
\text { cognitive fit }\end{array}$ & $\begin{array}{l}\text { Virtual } \\
\text { reality }\end{array}$ & Experiment & $\begin{array}{l}\text { Virtual reality interfaces increase consumer learning and } \\
\text { these effects extend to virtually high experiential products } \\
\text { more significantly than to virtually low experiential } \\
\text { products. }\end{array}$ \\
\hline $\begin{array}{l}\text { Wells, } \\
\text { Fuerst, and } \\
\text { Palmer } \\
(2005)\end{array}$ & $\begin{array}{l}\text { Exploring the use of } \\
\text { tangible attributes } \\
\text { derived from the } \\
\text { physical business } \\
\text { domain for } \\
\text { designing an } \\
\text { interface }\end{array}$ & $\begin{array}{l}\text { Metaphor } \\
\text { theory, } \\
\text { mental } \\
\text { model } \\
\text { theory }\end{array}$ & $\begin{array}{l}\text { Informatio } \\
\mathrm{n} \text { attributes }\end{array}$ & Experiment & $\begin{array}{l}\text { An interface based on the business domain metaphor } \\
\text { stimulates high levels of retention and recall of } \\
\text { information and thus provides the desired support for } \\
\text { experiential tasks. } \\
\text { Users with weaker domain familiarity show the greatest } \\
\text { improvement in retention and recall. }\end{array}$ \\
\hline $\begin{array}{l}\text { Wells et al. } \\
\text { (2011) }\end{array}$ & $\begin{array}{l}\text { Investigating how } \\
\text { website quality } \\
\text { serves as a signal } \\
\text { and influences } \\
\text { consumers' } \\
\text { perceptions of } \\
\text { product quality }\end{array}$ & $\begin{array}{l}\text { Signaling } \\
\text { theory }\end{array}$ & $\begin{array}{l}\text { Website } \\
\text { quality: } \\
\text { security, } \\
\text { download } \\
\text { delay, } \\
\text { navigabilit } \\
\text { y, visual } \\
\text { appeal }\end{array}$ & Experiment & $\begin{array}{l}\text { Website quality influences consumers' perceptions of } \\
\text { product quality, and the influence is stronger when } \\
\text { consumers experience higher information asymmetries. }\end{array}$ \\
\hline
\end{tabular}

This article is protected by copyright. All rights reserved. 


\begin{tabular}{|c|c|c|c|c|c|}
\hline Study & Object of Study & Theory & Factors & Method & Key Findings \\
\hline $\begin{array}{l}\text { Zhang } \\
(2006)\end{array}$ & $\begin{array}{l}\text { Investigating the } \\
\text { effect of animation } \\
\text { in the web } \\
\text { environment }\end{array}$ & Attention & Animation & Experiment & $\begin{array}{l}\text { Animation as a secondary stimulus deteriorates viewers' } \\
\text { information-seeking performance. } \\
\text { Animation that is brightly colored has a stronger negative } \\
\text { effect on viewer performance than does dull-colored } \\
\text { animation. }\end{array}$ \\
\hline
\end{tabular}

This article is protected by copyright. All rights reserved. 
Liu Libo (Orcid ID: 0000-0002-0431-7967)

Ho Susanna (Orcid ID: 0000-0002-9450-5776)

This article is protected by copyright. All rights reserved. 


\section{University Library}

\section{- M M I N E R VA A gateway to Melbourne's research publications}

Minerva Access is the Institutional Repository of The University of Melbourne

Author/s:

Zhang, Y;Liu, L;Ho, SY

Title:

How do interruptions affect user contributions on social commerce?

Date:

2020-05-01

Citation:

Zhang, Y., Liu, L. \& Ho, S. Y. (2020). How do interruptions affect user contributions on social commerce?. Information Systems Journal: an international journal promoting the study and practice of information systems, 30 (3), pp.535-565. https://doi.org/10.1111/isj.12266.

Persistent Link:

http://hdl.handle.net/11343/286375 